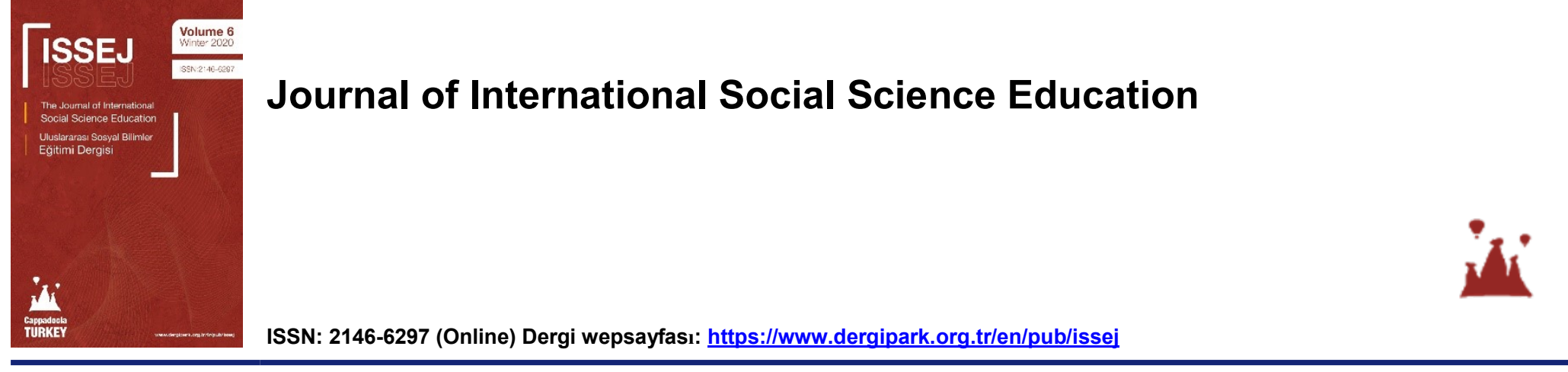

Sivas ilinde bal üreticilerinin sorunları ve çözüm önerileri

Önerilen atıf: (2020). Sivas ilinde bal üreticilerinin sorunları ve çözüm önerileri Makale başlığı, Uluslararası Sosyal Bilimler Eğitimi Dergisi, 6(2), 327-362 DOI:10.47615/issej.835332

Makale linki: https://doi.org/10.47615/issej.835332

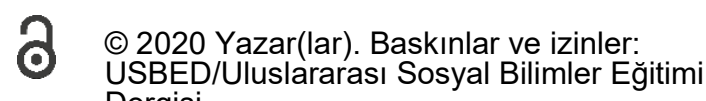
Dergis

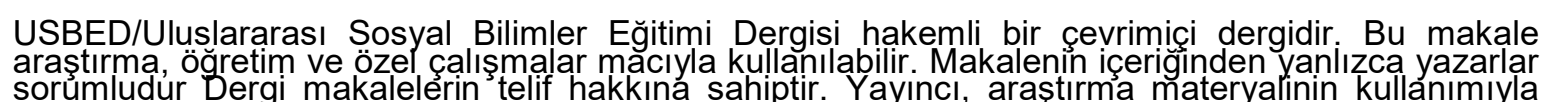
bağlantılı veya dogrudan veya dolaylı olarak ortaya çıkan herhangi bir kayıp, işlem, talep veya masraf veya zarardan sorumlu tutulamaz. 


\title{
Sivas ilinde bal üreticilerinin sorunları ve çözüm önerileri
}

\author{
Hakan KOÇ 이 Abdulkadır ERGÜN 1 Fatih KARTAL \\ Eğitim Fakültesi, Sivas Cumhuriyet Üniversitesi, Sivas, 58140, Türkiye
}

ÖZ

Arıcılık faaliyetinin yeryüzünde ilk olarak hangi tarihte yapılmaya başlandığı bilinmemekle birlikte yapılan araştırmalar bu faaliyetin milattan öncek dönemlere kadar dayandığını ortaya koymaktadır. 17. yüzyıla kadar ilkel bir şekilde yürütülen bu faaliyet, bu yüzyılda arıcılık alanında meydana gelen bir takım gelişmelerle modern bir şekilde yapılmaya başlanmış ve günümüzde dünya genelinde önemli bir tarımsal faaliyet haline gelmiştir. Dünya genelinde bu faaliyetin yürütüldüğü önemli alanlardan biri de Türkiye'dir. Dünya Tarım Örgütü (FAO)'nün 2018 yılı verilerine göre Türkiye kovan sayısı bakımından Hindistan ve Çin'den sonra üçüncü sırada, bal üretiminde ise Çin'den sonra ikinci sırada yer almaktadır

Büyük ölçüde doğal şartlara bağlı olarak yürütülen arıcılık faaliyetleri açısından Türkiye sahip olduğu topografya, iklim, bitki örtüsü ve su kaynakları açısından büyük bir potansiyele sahip olup, hemen hemen Türkiye'nin her bölgesinde bu faaliyet yürütülmektedir. Türkiye'de bu arıcılık faaliyetleri açısından öne çıkan alanlardan biri de Sivas Il'idir. Türkiye İstatistik Kurumu (TÜIK)'nun 2019 yılı verilerine göre Sivas Illi Ordu, Muğla ve Adana'dan sonra en fazla bal üretiminin gerçekleştirildiği dördüncü ildir. Bu çalışmada da Sivas İl'indeki bal üreticilerinin bu faaliyeti yürüttükleri sırada karşılaştıkları sorunları tespit ederek, bu sorunlara çözüm önerileri sunulmaya çalışılımıştır. Bu doğrultuda Sivas İl'inde en fazla bal üretiminin gerçekleştirildiği ilçelerden olan Yıldızeli, Imranlı, Koyulhisar, Gürün ve Divriği ilçelerinde toplam 164 bal üreticisi ile görüşme gerçekleştirilmiştir. Görüşme yapılan bal üreticilerine saha gezileri sırasında random yoluyla ulaşılmış ve araştırmacılar tarafından önceden hazırlanmış yarı yapılandırılmış görüşme formunda yer alan sorular yöneltilmiştir. Bal üreticilerinin bu sorulara vermiş oldukları cevaplar belirli temalar altında analiz edilerek, sorunlar ortaya konmuş ve bu sorunlara çözüm önerileri sunulmuştur.

MAKALE TARIHI

Geliș tarihi 03 Aralık 2020

Kabul tarihi 18 Aralık 2020

ANAHTAR KELIMER

Arıcilık, Bal, Sivas

Makale Türü

Araştırma makalesi

ILETișiM Abdulkadir Ergün@ anadolucografya1@gmail.com

(c) 2020 Hakan Koç, Abdulkadir Ergün, Fatih Kartal.

This is an Open Access article distributed under the terms of the Creative Commons Attribution-NonCommercial-NoDerivatives License (http://creativecommons.org/licenses/by-nc-nd/4.0/), which permits non-commercial re-use, distribution, and reproduction in any medium, provided the original work is properly cited, and is not altered, transformed, or built upon in any way. 


\title{
Problems and solution suggestions of honey producers in Sivas province
}

\author{
Hakan KOÇ 이 Abdulkadır ERGÜN $\bullet$ Fatih KARTAL \\ Faculty of Education, Sivas Republic University, Sivas, 58140, Turkey
}

$$
\text { ABSTRACT }
$$

ARTICLE HISTORY

Received 03 Aralik 2020

Although it is not clear when beekeeping (apiculture) first began on earth, studies have revealed that it dates back to the periods before Christ (BC). This KEYWORDS activity, which was carried out in a primitive manner until the $17^{\text {th }}$ century, Beekeeping, Honey, started to be implemented in a modern way with the help of some developments Sivas in the field of beekeeping and today has become an important agricultural activity worldwide. Turkey is one of the major areas for beekeeping globally. According to Food and Agriculture Organization (FAO) 2018 data, Turkey is ranked in the third place after China and India in terms of number of hives and in second place after China in honey production.

Since Turkey has great potential in terms of natural conditions such as topography, climate, flora and water resources which beekeeping activities which largely depend on, beekeeping can be carried out in all regions of Turkey. Sivas is one of the prominent apicultural areas in Turkey. Based on Turkish Statistical Institute 2019 data, Sivas is the fourth province after Ordu, Muğla and Adana in regards to honey production. This study aimed to identify the problems of honey producers in Sivas Province during beekeeping activities and to offer viable solutions. With this aim in mind, a total of 164 honey producers were interviewed in the districts of Yıldızeli, İmranlı, Koyulhisar, Gürün and Divriği, which are among the districts in Sivas with the highest honey production. The honey producers who were interviewed were reached randomly during the field trips with the help of the questions in the semi-structured interview from prepared by the researchers. The answers provided by these honey producers were analyzed under specific themes to reveal the problems and consequently viable solutions were presented. 
Giriş

Zar kanatlılar takımına ait Apoidea familyasına ait üyelerden biri olan bal arısının (Arıclık ve Bal Raporu, 2014; Üceş ve Erişir, 2016) bitkisel kaynakların kullanımına bağlı olarak bal, polen, arı sütü gibi ürünler elde etme faaliyetine aracılık denir. Arıcılık faaliyetleri ile sözü edilen ürünlerden başka propolis, arı zehiri gibi ürünler ve ana arı, oğul arı ve paket arı gibi canlı materyaller de üretilmektedir (Sancak, Zan Sancak ve Aygören, 2013).

Üretim amacıyla insanların arılardan ne zaman yararlanmaya başka bir ifade ile arıcılık faaliyetlerim tam olarak ne zaman başladığı ile ilgili kesin bilgiler bulunmamakla birlikte yapılan araştırmalar bu faaliyetin milattan önceki dönemlere kadar dayandığını ortaya koymaktadır. M. Ö 384-322 yılları arasında yaşayan Aristo'nun "Hayvanlar Tarihi" adlı eserinde arı tipleri ve kovan yaşamı hakkında bilgi vermesi, Hindistan'da M.Ö. 3000-2000 yillarına dair arıcıllk ve bala ait bilgilere ulaşılması, günümüzden 4000 yıl öncesine ait olan Firavun mezarlarında bal ve balmumlarının bulunması ve yine Misırlıların ayinlerinde balı kullanmaları ve kral hanedanlarından birisinin arıyı simge olarak kullanması ve M.Ö. 7000 yıllara ait olan mağara resimleri bu faaliyetin M.Ö. 7000'li yıllara kadar dayandığını göstermektedir (Sancak, Zan Sancak ve Aygören, 2013).

Arıcıllk faaliyetleri ilk insanların ağaç kovukları ve kaya oyuklarına yerleşmiş olan arıları öldürerek bu araların bu alanlarda biriktirmiş olduğu ballardan yararlanması ile başlamıştır (Arıclık ve Bal Roporu, 2014). Gerçek arıcılık insanların ağaç kovukları içerisinde yuvalanan arıları öldürmeden arıların yapmış olduğu balın bir miktarını almaları bir miktarını ise arılara bırakmaları şeklinde arılardan yararlanması ile başlamıştır (Toper Kaygın ve Yıldız, 2006; Arıclık ve Bal Raporu, 2014; Kaya, 2008). Arıların gen merkezlerinin Ortadoğu ülkeleri olması, arıcıllğıın bu ülkelerde ortaya çıktığı fikrini uyandırmaktadır (Kaya, 2008). Anadolu'da ise M.Ö. 1300'lü yıllara ait olduğu düşünülen Hititler devrinden kalma Boğazköy'deki taş yazıtlarda arılardan bahsedilmesi arıcılığın bu tarihlere kadar dayandığını ortaya koymaktadır (Yaygın Çiftçi Eğitim Projesi (YAYÇEP), 2001).

17. yüzyıla kadar ilkel bir biçimde yapılan arıcılık faaliyeti, bu alanda meydana gelen gelişmelere bağlı olarak büyük ilerlemeler kaydetmiştir. 1787 yılında ana arının havada çiftleştiğinin tespit edilmesi, 1845 yılında anı üreme biyolojisi hakkındaki bilgilerin ortaya konması, 1851 yılında çerçeveli fenni kovanın keşfedilmesi, 1857 yılında temel petek kalıplarının bulunması, 1865 yılında bal süzme makinasının icad edilmesi, 1882 yılında larva transfer yöntemiyle ana arı yetiştirme tekniğinin keşfedilmesi ve 1926 yılında ana arılarda yapay döllemenin bulunuşu arıcılık faaliyetlerine önemli katkılar sağlamıştır (Yaygın Çiftçi Eğitim Projesi (YAYÇEP), 2001). Bu gelişmelerin sayesinde ilerleme sağlayan arıcılık günümüzde dünya genelinde önemli bir tarımsal faaliyet haline gelmiş ve buna bağlı olarak kovan sayısı geçmişten günümüze artış göstermiştir.

Dünya Tarım Örgütü'nün (FAO) 1990'lı yılların başlarında dünya genelindeki toplam kovan sayıs1 70.000.000'un (69.237.913 adet) altındayken, 1995 y1lına kadar 3.300.000 civarında (3.304.241) bir azalmayla 66.000.000'un altına kadar (65.992.745) gerilemiştir. Bu dönemden sonra Dünya genelinde kovan sayıs1 
sürekli artış göstermiştir. 1997 yılında 65.000.000'un (65.933.672) üzerine çıkan dünya genelindeki kovan sayıs1 2001 yilında 70.000.000'un (70.393.523), 2006 y1linda 75.000.000'un (75.517.406), 2011 yllinda 80.000.000'un (80.403.600), 2014 yllinda 85.000 .000 'un (87.421.183) ve 2016 y1linda ise 90.000 .000 'un üzerine çıarak 90.188 .775 'e ulaşmıştır. 2018 yılında Dünya genelindeki kovan sayıs1 92.265.141'e ulaşmıştır (Grafik 1). 1990 yılından 2018 yılına kadar kovan sayısındaki artış \% 24 civarında gerçekleşmiştir.

Adet

95.000 .000

90.000 .000

85.000 .000

80.000 .000

75.000 .000

70.000 .000

65.000 .000

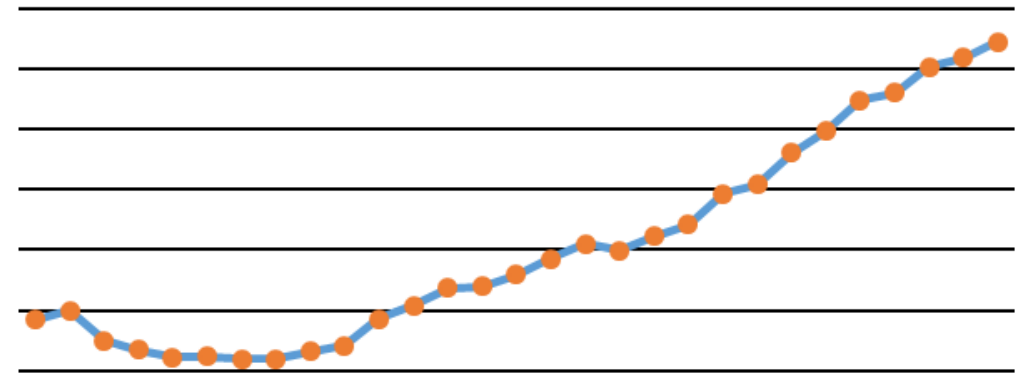

60.000 .000

55.000 .000

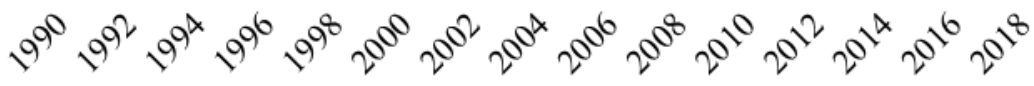

Grafik 1. 1990-2018 Yılları Arası Dünya Genelinde Kovan Sayısı

Kaynak: Food and Agriculture Organization Of The Uneted Nations (FAO), 2020.

Kovan sayısının ülkelere göre dağılımına bakıldığında 2018 yılı verilerine göre sekiz ülke dünya genelindeki kovan sayısının yarıdan fazlasını oluşturmaktadır (Tablo, 1).

Dünya genelindeki kovan sayısının yarıdan fazlasına sahip olan ülkelerden Hindistan \% 14,14 oran ile dünya genelinde en fazla kovana sahip ülkedir. Bu ülkeden sonra en fazla kovan sayısına sahip ülkeler oran olarak sırasıyla \%9,94 ile Çin, \%8,61 ile Türkiye, \% 7,15 ile İran, \% 6,52 ile Etiyopya, \% 3,45 ile Rusya ve $\%$ 3,27 ile Arjantin ve Tanzanya'dır. Bu sekiz ülkenin sahip olduğu kovan sayısı dünya genelindeki kovan sayısının \% 56,35'ini oluşturmaktadır (Tablo 1).

Bal üretiminde ise an fazla paya sahip ülke kovan sayısı en fazla ikinci ülke olan Çin (\% 24,70)'dir. Çin'den sonra en fazla bal üretimine sahip ülkeler sırasılyla Türkiye (\% 6,17), Arjantin (\% 4,29) İran (\% 4,19), Amerika Birleşik Devletleri (\% 3,73), Hindistan (\% 3,64), Rusya (\% 3,51) ve Meksika (\% 3,47)'dir (Tablo 1). Kovan sayısı en fazla ülke Hindistan olmasına rağmen, bal üretiminde ancak 5. sırada yer almaktadır. Bu durum ülkede kovan başına düşen üretim miktarının düşük olduğunu görmektedir. Gerek kovan sayısı gerekse bal üretiminde önemli paya sahip olan ülkelerden biri Türkiye'dir. Dünya genelinde Hindistan ve Çin'den 
sonra en fazla kovan sayısını sahip olan Türkiye, Çin'den sonra en fazla bal üretiminin gerçekleştirildiği ikinci ülkedir.

Tablo 1. 2018 Yılı Verilerine Göre Dünya Genelinde Kovan Sayısı 1.000.000'un Üzerine Olan Ülkeler.

\begin{tabular}{lrrrrr}
\hline Ülkeler & $\begin{array}{r}\text { Kovan } \\
\text { Sayıs } \\
\text { (Adet) }\end{array}$ & $\begin{array}{r}\text { Oran } \\
(\%)\end{array}$ & $\begin{array}{r}\text { Öretimi } \\
(\text { Ton) }\end{array}$ & $\begin{array}{r}\text { Oran } \\
(\%)\end{array}$ & $\begin{array}{r}\text { Verim } \\
(\text { Kg } / \text { Kovan } \\
\text { Sayıs })\end{array}$ \\
\hline Hindistan & 13.048 .275 & 14,14 & 67.442 & 3,64 & 5,17 \\
Çin & 9.173 .742 & 9,94 & 457.203 & 24,70 & 49,84 \\
Türkiye & 7.947 .687 & 8,61 & 114.113 & 6,17 & 14,36 \\
İran & 6.601 .394 & 7,15 & 77.567 & 4,19 & 11,75 \\
Etiyopya & 6.018 .223 & 6,52 & 50.000 & 2,70 & 8,31 \\
Rusya & 3.182 .399 & 3,45 & 65.006 & 3,51 & 20,43 \\
Arjantin & 3.020 .370 & 3,27 & 79.468 & 4,29 & 26,31 \\
Tanzanya & 3.019 .784 & 3,27 & 30.584 & 1,65 & 10,13 \\
İspanya & 2.965 .557 & 3,21 & 36.394 & 1,97 & 12,27 \\
ABD & 2.803 .000 & 3,04 & 69.104 & 3,73 & 24,65 \\
Meksika & 2.172 .107 & 2,35 & 64.253 & 3,47 & 29,58 \\
Kore & 2.165 .616 & 2,35 & 26.720 & 1,44 & 12,34 \\
Orta Afrika Cumhuriyeti & 1.679 .762 & 1,82 & 16.200 & 0,88 & 9,64 \\
Romanya & 1.602 .453 & 1,74 & 29.162 & 1,58 & 18,20 \\
Polonya & 1.586 .063 & 1,72 & 23.472 & 1,27 & 14,80 \\
Yunanistan & 1.556 .404 & 1,69 & 21.400 & 1,16 & 13,75 \\
Kenya & 1.533 .668 & 1,66 & 20.525 & 1,11 & 13,38 \\
Angola & 1.153 .618 & 1,25 & 23.411 & 1,26 & 20,29 \\
Brezilya & 1.017 .506 & 1,10 & 42.346 & 2,29 & 41,62 \\
Diğer Ülkeler & 20.017 .513 & 21,70 & 536.498 & 28,99 & 26,80 \\
Dünya Geneli & 92.265 .141 & 100 & 1.850 .868 & 100,00 & 20,06 \\
\hline
\end{tabular}

Kaynak: FAO, 2020.

Türkiye arıcılık faaliyetleri açısından elverişli koşullara sahip bir ülkedir. Zira arıcılık faaliyetleri ile topografya, iklim koşulları, flora ve hidrografik koşullar arasında sıkı bir ilişki vardır (Tuncel, 1992). Türkiye'de yeryüzü şekillerinin kısa mesafelerde ani değişiklikler göstermesi iklim ve bitki örtüsünün farklılaşmasına neden olmakta, böylece bitkilerin çiçeklenme dönemlerinde ve sürelerinde farklılıklara yol açarak neredeyse ülke genelinde arıcılık faaliyetinin yıl boyunca sürmesinde etkin rol oynamıştır. Ayrıca dağlık ve engebeli sahalarda ekip-biçmeye dayalı tarımsal alanların kısıtlı olması geçmiş yıllara kadar nüfusunun büyük bir bölümünün kırsal kesimde yaşadığ 1 ülkemizde insanların hayvancılık faaliyetlerine ve dolaysıyla da arıcılık faaliyetlerine yönelmesine neden olmuştur.

Bitki coğrafyası açısından ele alındığında ise Türkiye'de kuzeyinde Avrosibirya, doğusunda İran-Turan (Orta Asya), batısında ve güneyinde Akdeniz olmak üzere üç fitocoğrafya bölgesi yer almakla beraber, Güneydoğu Anadolu'da yer alan plato ve ovalar Mezopotamya Alt Bölgesi içerisinde kalmaktadır (Saya ve Güney, 2014). Türkiye'nin birden fazla fitocoğrafya bölgesinde yer alması ülkemizde bitki 
örtüsünün bölgelere göre farklılaşmasına ve arıcılık için ihtiyaç duyulan ballı bitkiler yönünden ülkemizin zengin bir potansiyele sahip olmasını sağlamaktadır. Türkiye arılar tarafindan önemli bir nektar kaynağı olarak değerlendirilen çam, köknar gibi salgı sağlayan ağaçlar ile akasya, ihlamur, akça ağaç, kestane gibi ağaçlar bakımından oldukça zengin bir genetik çeşitliliğe sahiptir (Kekeçoğlu vd., 2007). Türkiye bu potansiyeli ile Dünya ballı bitkiler florasının \% 75'ine sahiptir (Sancak ve diğerleri, 2013). Kekeçoğlu ve diğerleri (2007)'nin Kumova (2005)'dan aktardığına göre bal verimi yüksek ülkelerde bile bu verimliliğe rastlanılmamıştır. Ayrıca bu doğal bitki örtüsü ve arı meralarının dışında tarımsal alanların yonca, korunga, soya fasulyesi, ayçiçeği gibi yağlı tohum bitkilerinden, meyve ağaçlarının ise elma, narenciye, badem gibi ağaçlardan oluşması Türkiye'nin arıcılıktaki şansını daha da arttırmaktadır (Kekeçoğlu vd., 2007).

Arııılık faaliyetleri ile hidrografik koşullar asında da sıkı bir ilişki vardır. Arıcılık faaliyetlerinin yapıldığı bölgelerin yakınında arıların yararlanabileceği temiz bir su kaynağının olması gerekir (Tuncel, 1992). Türkiye yer aldığı bölgede hidrografik potansiyeli yüksek bir ülkedir. Türkiye'nin sahip olduğu yerüstü su kaynakları arıcılık faaliyetlerine olumlu etki yapmakta, bal üreticilerine bu konuda büyük avantajlar sağlamaktadır.

Yukarıda kısaca açıklanmaya çalışılan Türkiye'nin sahip olduğu topografya, iklim, flora ve hidrografya özellikleri arıcılık açısından önemli bir potansiyel sunmaktadır. Nitekim Türkiye Dünya genelinde kovan sayısı bakımından Hindistan ve Çin'den sonra üçüncü, bal üretiminde ise ikinci sırada yer almaktadır. Ancak kovan başına düşen verim açısından bal üretimi Dünya ortalamasının altındadır. Buna rağmen bugün Türkiye'nin hemen hemen her bölgesinde arıcilık faaliyetleri birincil veya ikincil ekonomik faaliyet olarak yürütülmekte, Muğla, Adana, Ordu gibi bazı iller arıcılık faaliyeti ve bal üretimi açısından öne çıkan sahalar olarak göze çarpmaktadır. Bu anlamda Türkiye'de arıcılık faaliyeti ve bal üretimi açısından öne çıkan çalışma sahalardan biri de Sivas İli'dir.

\section{Amaç}

Sivas İli sahip olduğu topografya, jeolojik, hidrografik ve flora özelliklerinden dolayı arıcılık faaliyetleri açısından büyük bir potansiyele sahiptir. İklim özellikleri açısından ise her ne kadar yıl içerisinde düşük sıcaklıklardan dolayı arıcılık faaliyetleri mayıs ve ekim ayları arasına sıkışmış olsa da yaz döneminde bunaltıcı sıcaklıkların olmaması arıcılık faaliyetleri açısından bir avantaj sağlamaktadır.

Arıcıllk faaliyetleri açsından elverişli doğal şartlara sahip olmasına rağmen Sivas İli'nde gelişmiş bir arıcılık faaliyetinden söz edilemez. Nitekim 2019 yılı verilerine göre Sivas İli Ordu, Muğla ve Adana'dan sonra 4. sırada yer almaktadır. Bal üretiminde ilk sırada yer alan Ordu Türkiye bal üretiminin \% 15,60'nı $(17.057,25$ ton) gerçekleştirirken, Muğla \% 13, 44 (14.688,48 ton) ve Adana ise \% 10,13'ünü (11.077,37 ton) gerçekleştirmektedir. Ordu, Muğla ve Adana'dan sonra 4. sirada yer alan Sivas İli ise Türkiye bal üretiminin \% 4,60'1nı (5.029,09 ton) gerçekleştirmekte olup, bu oran kendisinden önce yer alan ilk üç il ile 
kıyaslandığında aradaki farkın bayağı fazla olduğu görülmektedir. Bu durum ilde arıcılık ile uğraşan bireylerden kaynaklı bir takım sorunların olduğunu ortaya koymaktadır.

Bu çalışmanın amacı Sivas İli'ndeki bal üreticilerinin bu faaliyeti yürüttükleri sırada karşılaştıkları sorunları tespit edip bu sorunlara çözüm önerileri sunmaktır. $\mathrm{Bu}$ kapsamda araştırmada şu parametreler incelenmiştir:

- Arıcılıkla uğraşan bireylerin gezgin veya yerli arıcı olup olmadığ 1

- Arıcılıkla uğraşan bireylerin tercih ettikleri arı 1rkları

- Arıcılık faaliyetleriyle uğraşan bireylerin yıl içerisinde bu faaliyete başlama ve bitiş dönemi (Ay olarak)

- Arıcilıkla uğraşan her işletmenin sahip olduğu kovan sayısı

- Arıcılık faaliyetlerinden elde edilen ürünler ve miktarları (kg olarak)

- Arıcılık faaliyetlerinde elde edilen ürün miktarının yıllık bazda değişiklik gösterip göstermediği, değişiklik gösteriyorsa bu değişikliğin nedenleri

- Arıcılıkla uğraşan fertlerin materyalleri temin etme konusunda karşılaştıkları sorunlar

- Arıcılık ile uğraşan fertlerin bu faaliyeti yürüttüğü alanın iklim özellikleri hakkında bilgi düzeyleri

- Arıcılık ile uğraşan fertlerin bu faaliyeti yürüttüğü alanın bitki özellikleri hakkında bilgi düzeyleri

- Arıcılık ile uğraşan fertlerin iklim koşullarının olumsuz seyrettiği dönemde karşılaştıkları sorunlar ve bunlarla mücadele yöntemleri

- Arıcılık ile uğraşan fertlerin bu faaliyeti yürüttüğü alanda yürütülen diğer ekonomik faaliyetler hakkındaki bilgi düzeyleri

- Arıcılık ile uğraşan fertlerin bu faaliyeti yürütürken karşılaştıkları hastalıklar ve bunlarla mücadele ile ilgili sorunları

- Aracılıkla uğraşan fertlerin bu faaliyetten elde ettikleri ürünleri pazarlama ile ilgili sorunları

\section{Araștırma Sahasının Konumu, Doğal Çevre Özellikleri ve Arıcılık}

Araştırma sahası Sivas il sınırları içerisinde yer alan ve bal üretiminde öne çıkan Merkez, Yıldızeli, Hafik, Zara, İmranlı, Koyulhisar, Gürün ve Divriği ilçelerinden oluşmaktadır. Anadolu'nun orta kesiminde, İç Anadolu'nu platoluk sahalarından Doğu Anadolu'nun dağlık alanlarına geçiş güzergâhı üzerinde yer alan Sivas İli topraklarının büyük bir bölümü Yukarı Kızılırmak Havzası içinde yer almakla birlikte, Yeşilırmak ve Fırat havzaları içerisinde de toprakları bulunur. Yaklaşık $35^{\circ}-50^{\prime}$ ve $38^{\circ} 14^{\prime}$ doğu boylamları ile $38^{\circ}-32^{\prime}$ ve $40^{\circ}-16^{\prime}$ kuzey enlemleri arasında yer alan Sivas İli Kuzeyde Tokat, Doğu'da Erzincan, Güneydoğu'da Malatya, Güney'de Kahramanmaraş, Güneybatıda Kayseri, Batıda Yozgat, Kuzey ve Kuzeybatı'da ise Tokat illeri ile komşudur (Şekil 1). Yaklaşı $28.000 \mathrm{~km}^{2}$ alana sahip olan Sivas İli, Konya'dan sonra Türkiye'nin en büyük yüzölçümüne sahip ikinci ilidir. 


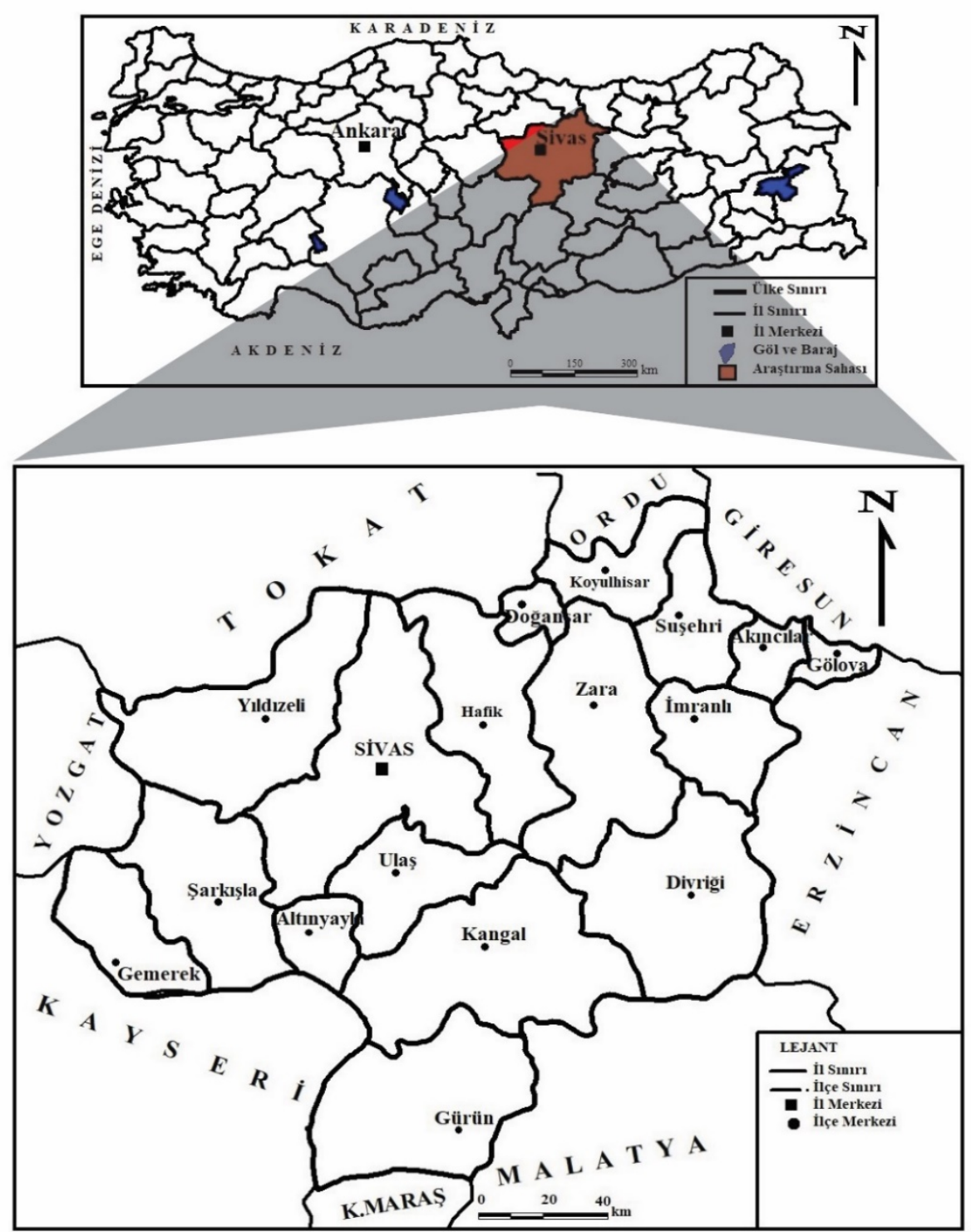

Şekil 1.Araştırma Sahasının Lokasyon Haritası.

Rakımı deniz seviyesinden oldukça yüksek olan Sivas İl genelinde yükselti değerleri 600-700 metre ile 2900-3000 metre aralığında değişmekte olup, ortalama yükselti değerleri 1500 metre civarındadır. İl genelinde göze çarpan yeryüzü şekillerinden en önemlisi dağlardır. Kuzey Anadolu dağlarının doğuya doğru uzantısı ile Karadeniz dağlarının birbirine doğru yaklaştığı bir sahada yer alan Sivas İli'nde dağlık sahalar önemli bir yer kaplar (Şekil 2).

Tablo 


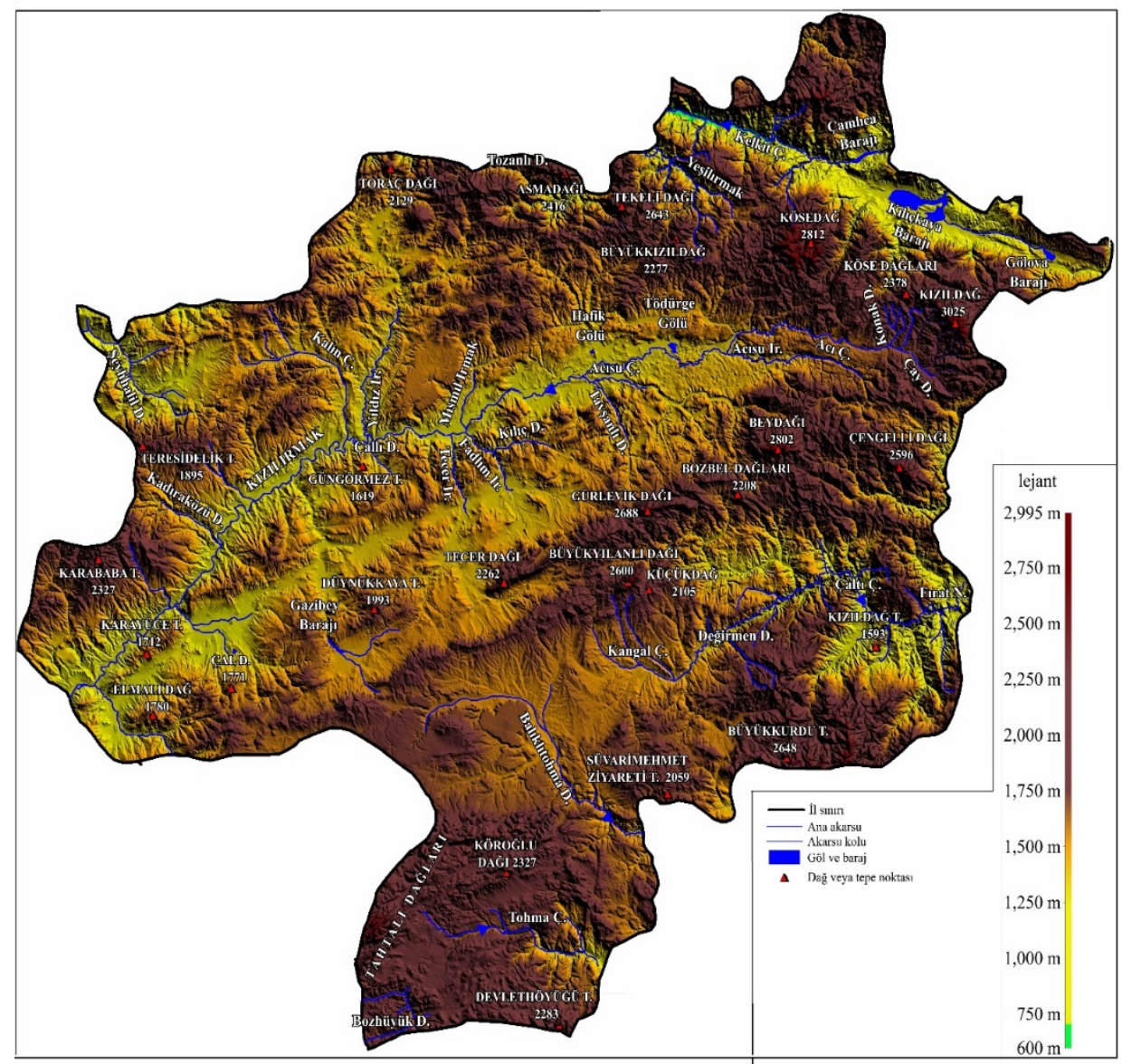

Şekil 2. Sivas İli Sayısal Yükselti Modeli (DEM) Haritası.

Kuzey Anadolu ve Güney Anadolu sıra dağlarının doğuya doğru olan uzantıları il sınırları içerisindeki dağlık sahaları oluşturmaktadır. Kuzey Anadolu dağ grubuna ait dağlar ilin kuzey kesimlerinde yer almakta olup, bu dağların başlıcaları batıdan doğuya doğru sırasiyla Asma Dağı $(2416 \mathrm{~m})$, Tekeli Dağ $(2643 \mathrm{~m})$, Büyük Kızıldağ (2277 m), Kösedağı (2812 m), Kösedağları (2378 m) ve Kızıldağ (3025 $\mathrm{m})$ 'dır. Güney Anadolu dağ grubu içerisinde yer alan dağlar ilin orta ve güney kesimlerinde uzanış göstermekte olup, bu dağların başlıcaları ilin orta kesimlerinde Tecer dağları (2262 m), Gürlevik Dağı $(2688 \mathrm{~m})$, Büyük Yılanlıdağ $1(2600 \mathrm{~m})$, Bozbel Dağları $(2208 \mathrm{~m})$, Bey dağları $(2802 \mathrm{~m})$ ve Çengelli Dağı $(2596 \mathrm{~m})$ ve güneyde Elmalıdağ (1780 m) Çalgal Dağı $(1771 \mathrm{~m})$ ve Köroğlu Dağı (2327 m)'dır.

İl sınırları içerisinde platoları il sınırları içerisinde yer kaplayan önemli morfolojik birimlerdendir (Ergün ve Buldur, 2016). İlin güneybatı kesimlerinde yer alan Uzunyayla ve şehir merkezinin kuzeyinde yer alan Meraküm platoları Sivas'ın önemli platolarındandır. Her iki plato da neojen tabakaları üzerinde gelişmiştir 
(Atalay, 1987). İldeki ovalar ise genel olarak yüzölçümleri küçük olup, bu alanların etrafı dağlık kütleler ile çevrilmiş durumdadır. Şarkışla, Gemerek, Yıldızeli, Suşehri ve Palanga ovaları il sınırları içerisinde önemli ovalardandır.

Sivas İli'nde topografyanın bu denli farklılık göstermesi arıcılık için elverişli şartlar oluşturmaktadır. Yükselti değerlerinin farklılık göstermesi iklim şartlarında farklılıklara neden olurken, aynı zamanda bitki örtüsünde çeşitliliğe yol açmakla birlikte bitkilerin çiçeklenme dönemleri ile sürelerinde de farkl1lıklar oluşturmaktadır. Yine il genelinde topografyanın engebeli olması ve yükselti değerleri ekip biçmeye dayalı tarımsal faaliyetleri kısıtladığ 1 için kırsal kesimde yaşayan nüfus hayvancıllı̆a ve arıcılık faaliyetlerine yönelmektedir.

İl topraklarının önemli bir bölümü Kızılırmak havzası içerisinde bulunan Sivas İli'nin Fırat ve Yeşilırmak havzaları içerisinde de toprakları yer alır. Bu durum ilin akarsular yönünden zengin olmasını sağlamıştır. Kızılırmak ve kolları Sivas'ın önemli akarsulardan olup, yine Firat ve Yeşilırmak nehirlerine ait kollar da il sınırları içerisinde akış göstermektedir. İl sınırları içerisinde yer alan göller ise gerek kapladıkları alan gerekse derinlikleri az olup, bu göllerin başlıcaları Hafik, Tödürge, Lota ve Gökpınar gölüdür (Şekil 2).

Yağış azamisi ilkbahara doğru kaymış "İç Anadolu Karasal İklim Tipi” nin etkisinde olan Sivas İli'nde uzun süreli rasat yapan meteoroloji istasyon verilerine göre yıllık sıcaklık ortalamaları $6,7^{\circ} \mathrm{C}$ ile $11,3{ }^{\circ} \mathrm{C}$ arasında değişmektedir. Aylık sicaklık ortalamaları ise en düşük $-6,0^{\circ} \mathrm{C}$, en yüksek $23,9^{\circ} \mathrm{C}$ 'dir (Tablo 2).

Tablo 2. Sivas Ili'nde Aylık ve Yıllık Ortalama Sıcaklıklar (1964-2017).

\begin{tabular}{lccccccccccccc}
\hline İstasyonlar & O. & Ş. & M. & N. & M. & H. & T. & A. & E. & E. & K. & A. & Ort. \\
\hline Merkez & $-3,6$ & $-2,2$ & 2,6 & 8,9 & 13,4 & 16,9 & 20,0 & 20,1 & 16,2 & 10,8 & 4,7 & $-0,8$ & 8,9 \\
Divriği & $-2,4$ & $-0,6$ & 4,7 & 10,6 & 15,2 & 19,6 & 23,7 & 23,7 & 19,3 & 13,0 & 5,9 & 0,5 & 11,1 \\
Gürün & $-2,5$ & 1,1 & 5,3 & 10,6 & 15,0 & 19,8 & 23,9 & 19,6 & 11,9 & 5,5 & 0,3 & 11,3 & 11,3 \\
Gemerek & $-3,3$ & $-1,6$ & 3,9 & 9,6 & 13,7 & 17,7 & 21,1 & 21,1 & 16,8 & 11,0 & 4,5 & $-0,5$ & 9,5 \\
Kangal & $-6,0$ & $-4,8$ & 0,5 & 6,7 & 11,1 & 15,0 & 18,5 & 18,5 & 13,9 & 8,3 & 2,0 & $-3,0$ & 6,7 \\
Suşehri & $-1,5$ & $-0,2$ & 4,3 & 10,0 & 14,2 & 17,9 & 20,9 & 21,0 & 17,5 & 12,5 & 6,1 & 0,9 & 10,3 \\
Ulaş (TiGEM) & $-3,0$ & $-1,5$ & 3,3 & 9,0 & 12,6 & 16,3 & 19,8 & 20,6 & 16,4 & 10,1 & 4,1 & $-1,3$ & 8,9 \\
Zara & $-3,6$ & $-2,5$ & 2,5 & 8,4 & 12,7 & 16,2 & 19,4 & 19,7 & 15,8 & 10,6 & 4,2 & $-1,0$ & 8,5 \\
\hline
\end{tabular}

Figure:Sivas İl Meteoroloji Müdürlüğü Verileri.

Sıcaklık şartlarının ülke genelinde düşük olması her ne kadar Sivas İli'ndeki arıcılık faaliyetlerinin süresini kısaltsa da bunaltıcı olmayan yaz sıcaklık değerleri bu faaliyet için elverişli koşullar sunmaktadır. Yapılan deneylerde sosyal bir topluluk olan arıların $29-33^{\circ} \mathrm{C}$ arasında çok faal oldukları, $10^{\circ} \mathrm{C}$ 'nin altında ve 37 ${ }^{\circ} \mathrm{C}$ 'nin üzerindeki sıcaklıklarda hiç faaliyette bulunmadıkları tespit edilmiştir (Tunçel, 1992, s.98). Sivas İli’nde yaz dönemi ortalama sıcaklıkları yaklaşık olarak $18^{\circ} \mathrm{C}$ ile $24^{\circ} \mathrm{C}$ arsında değişmektedir (Tablo 1.) 
Genel olarak İran-Turan fitocoğrafyasının Türkiye'deki ağaçsız sahalarına denk gelen kesimlerinde yer alan Sivas İli’nin (Saya ve Güney, 214) hâkim bitki örtüsü bozkırdır. Geven (Astragalus), Sığırkuyruğu (Verbascum), Peygamberçiçeği (Centaurea), Yavşanotu (Veronica), Kekik (Thmus falax), Yumak (Stipa), Çoban yastı̆̆1 (Acantholimon acerosum), Ebegümeci (Malva neglecta), Isırgan (Urtica dioica) ve Üzerlik (Oeganum Harmala) ilde yaygın olarak görülen bozkır bitki örtüsü türlerindendir.

Sivas İli'nde orman formasyonu genel olarak 1200-2600 metre arasındaki yükseltilerde yayılış göstermektedir (Orta Anadolu Kalkınma Ajansı (ORAN), 2011). İldeki bu bitki formasyonu yaygın olarak sarıçam (Pinus sylvestris), meşe (Quercus), karaçam (Pinus nigra) ağaçlarından oluşmaktadır (Atalay, 1994). Bu ağaç türlerinden başka kayın (Fagus orientalis), göknar (Abies cilicica) ve ardıç (Juniperus communius), gibi ağaç türleri de ilde görülen türlerdir (ORAN, 2011; Sivas Valiliği, 2011).

Arıcılık faaliyetinde arının hammaddesi olduğundan, il genelinde bitki örtüsünün çeşitlilik göstermesi bu faaliyet için büyük bir potansiyel sağlamaktadır. Çünkü bitki örtüsü arıcılığın devamlı olarak yapılmasında ve alınan verim üzerinde önemli bir etkiye sahiptir.

Sonuç olarak Sivas İli’nin sahip olduğu topografya, hidrografya, iklim ve vejetasyon gibi fiziki coğrafya şartları ilin arıcılık faaliyetleri açısından ne denli büyük bir potansiyele sahip olduğunu ortaya koymaktadır. Nitekim araştırma sahasında yapılan arazi çalışmaları sırasında gezgin arıcılara da rastlanılması ilin sahip olduğu fiziki coğrafya şartlarının arıcılık için ne denli önemli olduğunu ortaya koymaktadir.

\section{Metodoloji}

$\mathrm{Bu}$ çalışma genel tarama modelinde yapılan bir araştırmadır. "Tarama (survey) araştırmaları geniş gruplar üzerinde yürütülen, gruptaki bireylerin bir olgu veya olayla ilgili olarak görüşlerinin, tutumlarının alındiğı, olgu ve olayların betimlenmeye çalışıldı̆̆ araşstırmalardır" (Karakaya, 2009). Araştırmada veri toplama aracı olarak Sivas İli'nin Yıldızeli, Hafik, Zara, İmranlı, Koyulhisar, Gürün ve Divriği ilçelerinde arazi çalışmları sırasında random yoluyla ulaşılan 164 bal üreticisine uygulanan ve araştırmacılar tarafindan önceden oluşturumuş yarı yapılandırlmış ölçek formu kullanılmıştır. Bal üreticiler ile yüzyüze yapılan görüşmeler neticesinde ulaşılan görüş ve bilgiler betimsel analiz yöntemiyle değerlendirilmiştir.

"Betimsel analiz, çeşitli veri toplama teknikleri ile elde edilmiş verilerin daha önceden belirlenmiş temalara göre özetlenmesi ve yorumlanmasinı içeren bir nitel veri analiz türüdür. Betimsel analizde araştırmacı araştırma sorularında araştırmanin kavramsal çerçevesinde ya da görüşme ve gözlemlerde yer alan boyutlardan hareket ederek veri analizi için bir çerçeve oluşturur. Böylece verilerin hangi temalar altında düzenleneceği ve sunulacă̆ belirlenmiş olur. 
Ardından araştırmacı daha önce oluşturmuş olduğu çerçeveye dayalı olarak verileri okur ve düzenler. Bu süreçte verilerin anlamlı ve mantıklı bir biçimde bir araya getirilmesi önem taşımaktadır. Bu aşamadan sonra araştırmacı düzenlemiş olduğu verileri tanımlar. Bunun için gerekli olduğu yerlerde doğrudan alıntılara da başvurmak zorunda kalabilir. Bu sürecin sonucunda araştırmacı tanımlamış olduğu bulguları açıklar, ilişkilendirir ve anlamlandırır. Araştırmacı bu aşamada ayrıca yapmış olduğu yorumları daha da güçlendirmek için bulgular arasındaki neden sonuç ilişkilerini açıklar ve ihtiyaç duyulması durumunda farklı olgular arasında karılaştırma yapar" (Yıldırım ve Şimşek, 2005).

\section{Çalıșma Grubu}

Araştırmanın çalışma grubunu, Sivas İli'ne bağlı Yıldızeli, İmranlı, Koyulhisar, Gürün ve Divriği ilçelerinde arazi çalışması sırasında random yoluyla ulaşılan toplam 164 bal üreticisi oluşturmaktadır.

\section{Verilerin Analizi}

Görüsşmede üreticilere sorulmak amacıyla hazırlanmış ve araştırmanın amacı kısmında bahsedilen parametreler hakkındaki soruları içeren yarı yapılandırılmış ölçek formu kullanılmış olup, bal üreticilerinin yarı yapılandırılmış ölçekteki sorulara vermiş oldukları cevaplar ve saha gözlemleri sonucunda ulaşılan görüş ve bilgiler betimsel analiz yöntemiyle değerlendirilmiştir.

\section{Bulgular}

Araştırmanın bu bölümünde araştırmacılar tarafından hazırlanmış yarı yapılandırılmış ölçekte yer alan sorulara bal üreticilerinin vermiş oldukları cevaplar belirli temalara göre gruplandırılıp, analiz edilmiş ve değerlendirilmiştir.

\section{Sivas İli’nde Arıcılıkla Uğrașan Bireylerin Gezgin Veya Yerli Arıcı Olma Durumlar1}

Sivas İli yerli arıcıların yanısıra, arıcılık için sahip olduğu potansiyelden dolayı il dışındaki arıcıların da bu faaliyeti yürütmek için tercih ettikleri bir sahadır. Araştırma sahasında görüşme yapılan bal üreticilerinin \% 56,7'si yerli arıcılardan oluşurken, \% 23,2'si Sivas il dışından gelenlerden yani gezgin arıcılardan, \% 20,1'i ise il dışına gidenlerden oluşmaktadır. Yine araştırma sahasında görüşme yapılan ilçelerin tamamında yerli arıcılar ağırlıkta olmakla birlikte, özellikle İmranl, Koyulhisar ve Zara'da gezgin arıcıların da yoğunlukta olduğu saha gözlemlerinde belirlenmiştir (Tablo 3).

Sivas İli'ni en fazla Ordu İli'nden gelen gezgin arıcılar tercih etmektedirler. Saha çalışması yapılan ilçelerin tamamında bu ilden gelen arıcılarla karşılaşılmıştır. 
Araştırma sahasına Ordu İli’nden sonra en fazla gezgin arıcıların geldiği bir diğer il Tokat ve Amasya illeridir. Saha çalışmasının yapıldı̆̆ 1 altı ilçenin dördünde (İmranlı, Koyulhisar, Zara ve Yıldızeli) bu iki ilden gelen arıcılarla karşılaşılmıştır. Ordu, Tokat ve Amasya illerinden başka yörede Mersin ve Bafra'dan gelen arıcılar da bulunmaktadır. Araştırma sahasına yöre dışından gelen gezgin arıcıların en fazla tercih ettikleri ilçeler İmranl, Koyulhisar ve Zara ilçeleridir (Tablo 3).

Sivas İl dışına giden gezgin arıcılar ise ağırlıklı olarak Antalya, Muğla, Mersin ve Ordu illerini tercih etmektedirler. Bu illerden başka yöre dışına giden gezgin arıcılar Hatay, Adana, Muş illerini tercih etmekle beraber az da olsa yörede Tokat, Erzincan, Amasya, Osmaniye gibi illeri tercih eden gezgin arıcılar da bulunmaktadır. Araştırma sahasında yöre dışına en fazla Divriği (7 kişi), Gürün, Koyulhisar ve Yıldızeli (6 kişi) ilçelerindeki arıcılar gitmektedirler (Tablo 3).

Tablo 3. Sivas Ili'nde Arıclık Faaliyetinde Bulunan Bireylerin Yerli Veya Gezgin Arıcı Olma Durumu.

\begin{tabular}{|c|c|c|c|c|c|c|c|c|}
\hline & Divriği & Gürün & İmranlı & Koyulhisar & Yıldızeli & Zara & $\begin{array}{c}\text { Toplam } \\
\text { (Kişi) }\end{array}$ & $\begin{array}{c}\text { Yüzde } \\
(\%)\end{array}$ \\
\hline Yerli & 24 & 16 & 11 & 10 & 13 & 19 & 93 & 56,7 \\
\hline $\begin{array}{l}\text { Gezici } \\
\text { yöre } \\
\text { dışından } \\
\text { gelen }\end{array}$ & $\begin{array}{c}2 \\
\text { (Ordu) }\end{array}$ & $\begin{array}{c}3 \\
\text { (Ordu) }\end{array}$ & $\begin{array}{c}9 \\
\text { (Mersin } \\
\text { Ordu } \\
\text { Amasya } \\
\text { Tokat) }\end{array}$ & $\begin{array}{c}10 \\
\text { (Ordu } \\
\text { Bafra } \\
\text { Amasya } \\
\text { Tokat) }\end{array}$ & $\begin{array}{c}2 \\
\text { (Ordu } \\
\text { Bafra, } \\
\text { Amasya } \\
\text { Tokat) }\end{array}$ & $\begin{array}{c}12 \\
\text { (Ordu } \\
\text { Amasya } \\
\text { Tokat) }\end{array}$ & 38 & 23,2 \\
\hline $\begin{array}{l}\text { Gezici } \\
\text { yöre } \\
\text { dışına } \\
\text { giden }\end{array}$ & $\begin{array}{c}7 \\
\text { (Antalya } \\
\text { Muğla } \\
\text { Mersin) }\end{array}$ & $\begin{array}{c}6 \\
\text { (Antalya } \\
\text { Adana } \\
\text { Tokat } \\
\text { Hatay } \\
\text { Erzincan } \\
\text { Osmaniye } \\
\text { Mersin } \\
\text { Antalya } \\
\text { Muğla) }\end{array}$ & $\begin{array}{c}5 \\
\text { (Ordu } \\
\text { Bafra } \\
\text { Hakkâri } \\
\text { Muş } \\
\text { Erzurum } \\
\text { Kars } \\
\text { Hatay } \\
\text { Muğla } \\
\text { Amasya } \\
\text { Tokat } \\
\text { Mersin } \\
\text { Adana) }\end{array}$ & $\begin{array}{c}6 \\
\text { (Muğla } \\
\text { Antalya } \\
\text { Mersin } \\
\text { Ordu) }\end{array}$ & $\begin{array}{c}6 \\
\text { (Ordu } \\
\text { Antalya } \\
\text { Muğla) }\end{array}$ & $\begin{array}{c}3 \\
\text { (Mersin } \\
\text { Antalya } \\
\text { Muğla } \\
\text { Hatay } \\
\text { Ordu } \\
\text { Muş } \\
\text { Adana) }\end{array}$ & 33 & 20,1 \\
\hline $\begin{array}{c}\text { Toplam } \\
\text { (Kişi) }\end{array}$ & 33 & 25 & 25 & 26 & 21 & 34 & 164 & 100 \\
\hline
\end{tabular}

\section{Sivas İli’nde Arıcılık İle Uğrașan Bireylerin Tercih Ettikleri Arı Irkları}

Araştırma sahasında bal üreticileri ile yapılan görüşmelerden elde edilen bulgulara göre Sivas İli'nde arıcılık faaliyetinde en fazla tercih edilen arı ırkı Kafkas Arısı (\% $78,7)$ 'dir. Bu arı türünden sonra arıcıların en fazla tercih edilen arı 1rkı Karnion (\% $18,1)$ 'dur. Bu iki arı ırkından başka yörede az da olsa İtalyan (\% 2,1) ve Alman Arısı ( \% 1,1) 1rkları da tercih edilmektedir (Tablo 4). 
Tablo 4. Sivas Ili'nde Arıcılıkla Uğraşan Bireylerin Tercih Ettikleri Arı Irkları.

\begin{tabular}{|c|c|c|c|c|c|c|c|c|}
\hline Arı ırkları & Divriği & Gürün & İmranlı & Koyulhisar & Yıldızeli & Zara & $\begin{array}{l}\text { Toplam } \\
\text { (Cevap) }\end{array}$ & $\begin{array}{c}\text { Yüzde } \\
(\%)\end{array}$ \\
\hline $\begin{array}{l}\text { Kafkas } \\
\text { Arısı }\end{array}$ & 30 & 25 & 24 & 25 & 20 & 28 & 152 & 78,7 \\
\hline Karnion & 8 & 6 & 4 & 5 & 2 & 10 & 35 & $\% 18,1$ \\
\hline $\begin{array}{l}\text { Alman } \\
\text { Arısı } \\
\text { İtalyan }\end{array}$ & 1 & & 1 & 1 & 1 & 1 & 2 & 1,1 \\
\hline $\begin{array}{l}\text { Toplam } \\
\text { (Cevap) }\end{array}$ & 39 & 31 & 29 & 31 & 23 & 40 & 193 & 100 \\
\hline
\end{tabular}

Tablo 4'de de görüldüğü gibi Kafkas Arısı yörenin genelinde en fazla tercih edilen arı 1rkı iken, bu 1rktan sonra en fazla tercih edilen arı 1rkı olan Karnion ise Divriği ve Zara ilçelerinde daha çok tercih edilmektedir.

\section{Arıcılık Faaliyetleriyle Uğrașan Bireylerin Yıl İçerisinde Bu Faaliyete Bașlama ve Bitiș Dönemi}

Sivas İli'nde arıcılık faaliyetleri mart-eylül ayları arasında yoğunlaşmaktadır ( \% 35,3). Bu dönemden sonra arıcılık faaliyetinin yoğunlaştığı dönem ocak-aralık aylarıdır (\% 23,1; Tablo 5). İl genelinde bu dönemde sıcaklık ortalamaları $0{ }^{\circ} \mathrm{C}$ 'nin altında olan aylar bulunmasına rağmen arıcılık faaliyetlerinin bu dönemde yoğunlaşması gezgin arıcılardan kaynaklanmaktadır. Zira tablo 2'de görüldüğü gibi görüşme yapılan arıcılardan alınan cevaplara göre arıcıların \% 20,'i gezgin arıcı olup, bunlar bu dönemde Adana, Mersin, Muğla, Hatay gibi sıcak illerde bu faaliyeti yürütmektedirler. İlde arıcılık faaliyetlerinin yoğun olarak yapıldığı bir diğer dönem ise nisan-ekim (\% 14,7) ayları arasıdır.

Tablo 5. Sivas İli'nde Arıcılık Faaliyeti İle Uğraşan Bireylerin Bu Faaliyeti Yürüttükleri Dönemler.

\begin{tabular}{|c|c|c|c|c|c|c|c|c|}
\hline Dönem & Divriği & Gürün & İmranlı & Koyulhisar & Yıldızeli & Zara & $\begin{array}{c}\text { Toplam } \\
\text { (Kişi) }\end{array}$ & $\begin{array}{c}\begin{array}{c}\text { Yüzde } \\
(\%)\end{array} \\
\text { (\%) }\end{array}$ \\
\hline $\begin{array}{l}\text { Mart- } \\
\text { Eylül }\end{array}$ & 17 & 5 & 3 & 14 & 15 & 4 & 58 & 35,3 \\
\hline $\begin{array}{l}\text { Nisan- } \\
\text { Kasım }\end{array}$ & 1 & 4 & 2 & 3 & 1 & 4 & 15 & 9,1 \\
\hline $\begin{array}{l}\text { Nisan- } \\
\text { Ekim }\end{array}$ & 3 & 4 & 11 & 3 & 1 & 2 & 24 & 14,7 \\
\hline $\begin{array}{l}\text { Şubat- } \\
\text { Kasım }\end{array}$ & 2 & 3 & 4 & 2 & 1 & 2 & 14 & 8,6 \\
\hline $\begin{array}{l}\text { Ocak- } \\
\text { Aralık }\end{array}$ & 8 & 6 & 2 & 2 & 1 & 19 & 38 & 23,1 \\
\hline $\begin{array}{l}\text { Mart- } \\
\text { Ağustos }\end{array}$ & 2 & 3 & 3 & 2 & 2 & 3 & 15 & 9,2 \\
\hline $\begin{array}{c}\text { Toplam } \\
\text { (Kişi) }\end{array}$ & 33 & 25 & 25 & 26 & 21 & 34 & 164 & 100 \\
\hline
\end{tabular}

Divriği, Koyulhisar ve Yıldızeli ilçelerinde arıcılık faaliyetleri mart-eylül ayları arasında yoğunlaşırken, İmranlı'da nisan-ekim aylarında yoğunlaşmaktadır (Tablo 5). İmranlı 'da aylık sıcaklık ortalamaları diğer merkezlere göre düşük olduğunda 
dolayı bu yöredeki bal üreticilerinin bu faaliyete başlama dönemleri Divriği, Koyulhisar ve Yıldızeli ilçelerine göre geç olmaktadır. Zara'da ise gezgin arıcıların yoğunlukta olmasından dolayı arıcılık faaliyetleri yılın tamamına yayılmış vaziyettedir.

\section{Sivas İli'nde Arıcılıkla Uğrașan Kișilerin Sahip Oldukları Kovan Sayısı}

Sivas İli'nde arıcılık faaliyeti ile uğraşan bireylerin sahip oldukları kovan sayıları ağırlıklı olarak 1-50 adet arasındadır. İl genelinde görüşme yapılan bal üreticilerin $\%$ 22, 4'ünün kovan sayısı bu aralıktadır. Görüşme yapılan bal üreticilerinin \% 20,1'inin ise sahip oldukları kovan sayıs1 50-100 adet arasındadır (Tablo 6). Dolaysıyla görüşme yapılan bal üreticilerinin \% 42, 5'inin sahip olduğu kovan sayıs1 1-100 adet arasında olup, bu durum ildeki arıcılık faaliyetlerinin küçük işletmeler şeklinde yürütüldüğünü göstermektedir.

İl genelinde 1-100 adet arasındaki kovan sayısında sonra en fazla sahip olunan kovan sayıları sirasiyla 350-400 (\% 11,5), 300-350 ile 100-150 (\% 10,4) ve 150$200(\% 10,2)$ arasıdır. Sahip olunan en az kovan sayıs ise 200-250 ( \% 5,3) aralığındadır (Tablo 6).

Tablo 6. Sivas Ili'nde Bal Üreticilerinin Sahip Oldukları Kovan Sayıları.

\begin{tabular}{|c|c|c|c|c|c|c|c|c|}
\hline $\begin{array}{l}\text { Kovan } \\
\text { sayısı }\end{array}$ & Divriği & Gürün & İmranlı & Koyulhisar & Yıldızeli & Zara & $\begin{array}{c}\text { Toplam } \\
\text { (Kişi ) }\end{array}$ & $\begin{array}{c}\text { Yüzde } \\
(\%)\end{array}$ \\
\hline $1-50$ & 15 & 10 & 2 & 2 & 6 & 2 & 37 & 22,4 \\
\hline $50-100$ & 12 & 9 & 2 & $\overline{1}$ & 7 & 2 & 33 & 20,1 \\
\hline $100-150$ & 3 & 3 & 2 & 3 & 5 & 2 & 18 & 10,4 \\
\hline $150-200$ & 2 & 2 & 2 & 2 & 3 & 3 & 17 & 10,2 \\
\hline $200-250$ & 1 & $\overline{1}$ & 2 & $\overline{1}$ & & 4 & 9 & 5,3 \\
\hline $250-300$ & & & 5 & 5 & & 6 & 16 & 9,7 \\
\hline $300-350$ & & & 5 & 6 & & 7 & 18 & 10,4 \\
\hline $350-400$ & & & 5 & 6 & & 8 & 19 & 11,5 \\
\hline $\begin{array}{c}\text { Toplam } \\
\text { (Kişi) }\end{array}$ & 33 & 25 & 25 & 26 & 21 & 34 & 164 & 100 \\
\hline $\begin{array}{c}\text { Eski } \\
\text { kovan }\end{array}$ & 150 & 145 & 178 & 120 & 115 & 172 & 880 & 10,4 \\
\hline $\begin{array}{c}\text { Yeni } \\
\text { kovan }\end{array}$ & 1224 & 921 & 1420 & 1528 & 623 & 1835 & 7551 & 89,6 \\
\hline $\begin{array}{l}\text { Toplam } \\
\text { Kovan } \\
\text { Sayısı }\end{array}$ & 1374 & 1066 & 1598 & 1648 & 738 & 2007 & 8431 & 100 \\
\hline
\end{tabular}

İlçeler bazında bakıldığında ise Divriği ve Gürün ilçelerindeki işletmelerin sahip olduğu kovan sayıları ağırlıklı olarak 1-50 ve 50-100 aralı̆ğında iken, İmranlı, Koyulhisar ve Zara ilçelerindeki işletmelerin sahip oldukları kovan sayılarının ağırlıklı olarak 300-350 ve 350-400 aralığında yoğunlaştığı görülmektedir.

İl genelinde arazi çalışması yapılan ilçelerin tamamında yeni kovan kullanımının yaygın olduğu görülmektedir. Görüşme yapılan bal üreticilerinin sahip olduğu 8431 kovanın \% 89,6's1 (7551 adet) yeni kovan, \% 10,4'ü (880 kovan) ise eski kovandır (Tablo 6). 
Sivas İli'nde Arıcılık Faaliyetiyle Uğrașan Bireylerin Bu Faaliyetten Elde Etikleri Bal Miktarı (kg olarak) ve Diğer Ürünler

Arıcılık faaliyetinde asıl amaç bal üretimi olmakla birlikte bunun yanında polen, arı sütü, propolis ve bal mumu gibi ürünler de elde edilmektedir.

Araştırma sahasında görüşme yapılan bal üreticilerinin yıllık elde ettikleri bal miktarı ağırlıklı olarak $1000 \mathrm{~kg}$ ve üzerindedir. Araştırma sahasında görüşme yapılan bal üreticilerinin \% 40,3'ünün yıllık bal miktarı $100 \mathrm{~kg}$ ve üzerindedir. Y1llık bal üretim miktarı $500-1000 \mathrm{~kg}$ arasında olan üreticilerin oranı \% 30,4'tür. Saha gezisi yapılan ilçelerin tamamında en fazla üretimi bu iki değerde gerçekleştirilmektedir Dolaysıyla araştırma sahasında görüşme yapılan bal üreticilerini \% 70'7'si gibi büyük bir çoğunluğunun yılllk bal üretimi $500 \mathrm{~kg}$ üzerindedir (Tablo 5). Bu durum ildeki arıcılık faaliyetlerinin ticari amaçla yapıldığını ortaya koyması açısından oldukça önemlidir. Bu değerden sonra miktar olarak bal üretimin gerçekleştirildiği aralık 100-500 kg aralığında olup, görüşme yapılan üreticilerin \% 30,4'ü bu aralıkta yıllık üretim gerçekleştirmektedirler.

$\mathrm{Bu}$ değerlerden başka Divriği'de 2 üretici, Gürün ve Zara'da 3 üretici olmak üzere toplam 8 üretici $(\% 4,8) 80-100 \mathrm{~kg}$ arasında, Gürün ve Koyulhisar'da 2 üretici, Yıldızeli'nde 3 üretici olmak üzere toplam 7 üretici $(\% 4,2) 60-80 \mathrm{~kg}$ arasında yıllık bal üretimi gerçekleştirmektedir. Y1llık bal üretiminin en az gerçekleştirildiği 0-20 kg aralığında ise Divriği'de 2, İmranlı ve Yıldızeli’nde 1 üretici olmak üzere toplam 4 üretici $(\% 2,4)$ bulunmaktadır (Tablo 7).

Tablo 7. Araştırma Sahasında Üreticilerin Elde Ettikleri Yıllık Bal Miktarı (Kg).

\begin{tabular}{ccccccccc}
\hline Bal (Kg) & Divriği & Gürün & İmranlı & Koyulhisar & Yıldızeli & Zara & $\begin{array}{c}\text { Toplam } \\
\text { (Kişi) }\end{array}$ & $\begin{array}{c}\text { Yüzde } \\
\text { (\%) }\end{array}$ \\
\hline $0-20$ & 2 & & 1 & & 1 & & $\mathbf{4}$ & $\mathbf{2 , 4}$ \\
$20-40$ & & & & & 2 & & $\mathbf{2}$ & $\mathbf{1 , 3}$ \\
$40-60$ & 1 & 1 & 2 & & & 1 & $\mathbf{5}$ & $\mathbf{3 , 1}$ \\
$60-80$ & & 2 & & 2 & 3 & & $\mathbf{7}$ & $\mathbf{4 , 2}$ \\
$80-100$ & 2 & 3 & & & & 3 & $\mathbf{8}$ & $\mathbf{4 , 8}$ \\
$100-500$ & 8 & 7 & & & 3 & 4 & $\mathbf{2 2}$ & $\mathbf{1 3 , 5}$ \\
$500-1000$ & 10 & 6 & 9 & 12 & 5 & 8 & $\mathbf{5 0}$ & $\mathbf{3 0 , 4}$ \\
$\begin{array}{c}1000 \text { ve } \\
\text { üzeri }\end{array}$ & 10 & 6 & 13 & 12 & 7 & 18 & $\mathbf{6 6}$ & $\mathbf{4 0 , 3}$ \\
\hline $\begin{array}{c}\text { Toplam } \\
\text { (Kişi) }\end{array}$ & $\mathbf{3 3}$ & $\mathbf{2 5}$ & $\mathbf{2 5}$ & $\mathbf{2 6}$ & $\mathbf{2 1}$ & $\mathbf{3 4}$ & $\mathbf{1 6 4}$ & $\mathbf{1 0 0}$ \\
\hline
\end{tabular}

Araştırma sahasında arıcılık faaliyetlerinden bal dışı ürünler de üretilmektedir. Yörede üreticilerle yapılan görüşmelerde arıcılık faaliyetlerinden bal dışında elde edilen ürünlerle ilgili verilen cevaplara göre en fazla polen üretimi (\% 44,3) gerçekleştirilmektedir. Polenden sonra en fazla üretimi gerçekleştirilen ürün arı sütü $(\% 25,3)$ ve propolis olup en az üretimi gerçekleştirilen ürün ise bal mumu (\% $11,8)$ 'dur (Tablo 8). 
Tablo 8. Araştırma Sahasında Üreticilerin Bal Haricinde Ürettikleri Ürünler.

\begin{tabular}{ccccccccc}
\hline $\begin{array}{c}\text { Bal harici } \\
\text { ürünler }\end{array}$ & Divriği & Gürün & İmranlı & Koyulhisar & Yıldızeli & Zara & $\begin{array}{c}\text { Toplam } \\
\text { (Cevap) }\end{array}$ & $\begin{array}{c}\text { Yüzde } \\
\text { (\%) }\end{array}$ \\
\hline Polen & 19 & 15 & 18 & 20 & 15 & 25 & $\mathbf{1 1 2}$ & $\mathbf{4 4 , 3}$ \\
Arı Sütü & 5 & 10 & 8 & 12 & 14 & 15 & $\mathbf{6 4}$ & $\mathbf{2 5 . 3}$ \\
Propolis & 8 & 5 & 7 & 6 & 9 & 12 & $\mathbf{4 7}$ & $\mathbf{1 8 . 6}$ \\
Bal Mumu & 3 & 4 & 5 & 6 & 4 & 8 & $\mathbf{3 0}$ & $\mathbf{1 1 . 8}$ \\
\hline $\begin{array}{c}\text { Toplam } \\
\text { (Cevap) }\end{array}$ & $\mathbf{3 5}$ & $\mathbf{3 4}$ & $\mathbf{3 8}$ & $\mathbf{4 4}$ & $\mathbf{4 2}$ & $\mathbf{6 0}$ & $\mathbf{2 5 3}$ & \\
\hline
\end{tabular}

Araştırma sahasındaki ilçelerin tamamında bal haricindeki diğer ürünlere göre en fazla polen üretimi öne çıkmaktadır. Bu üründen başka arı sütü üretimi de en fazla Divriği hariç diğer ilçelerin tamamında polenden sonra öne çıkarken, Divriği İlçesi'nde polenden sonra propolis üretimi öne çıkmaktadır. Divriğii'den başka Zara ve Koyulhisar ilçeleri de propolis üretiminin en fazla gerçekleştirildiği ilçelerdir. Bal mumu ise ilçelerin tamamında üretimi en az gerçekleştirilen üründür (Tablo 7).

\section{Sivas Ili'nde Arıcılık Faaliyetlerinden Elde Edilen Ürünün Yıllık Bazda Değişiklik Gösterip Göstermeme Durumu}

Üreticilerden alınan cevaplara göre araştırma sahasında arıcılık faaliyetinden elde edilen ürün miktarının yıllar itibariyle değişiklik gösterdiği görülmektedir. Bu değişimin nedeni olarak ise yine üreticilerin vermiş olduğu cevaplara göre iklim faktörü olduğu anlaşılmaktadır. Araştırmaya katılan tüm ilçelerdeki bal üreticileri üretimde meydana gelen değişimin sebebini iklim koşullarına bağlamaktadırlar (Tablo 9).

Tablo 9. Sivas Illi'nde Arıcılık Faaliyetinden Elde Edilen Ürün Miktarının Yıllara Göre Değişiklik Göstermesinin Sebepleri.

\begin{tabular}{cccccccc}
\hline Sebepler & Divriği & Gürün & İmranlı & Koyulhisar & Yıldızeli & Zara & Toplam (Kişi) \\
\hline İklim & 33 & 25 & 25 & 26 & 21 & 34 & 164 \\
$\begin{array}{c}\text { Toplam } \\
\text { (Kişi) }\end{array}$ & $\mathbf{3 3}$ & $\mathbf{2 5}$ & $\mathbf{2 5}$ & $\mathbf{2 6}$ & $\mathbf{2 1}$ & $\mathbf{3 4}$ & $\mathbf{1 6 4}$ \\
\hline
\end{tabular}

Üreticilerden elde edilen bilgilere göre iklim şartlarının elverişli olduğu dönemlerde arıcılık faaliyetlerinden elde edilen ürün miktarında artış olurken, iklim şartlarının elverişsiz olduğu dönemlerde ise ürün miktarında azalmalar olmaktadır. Görüşme yapılan üreticilerden alınan cevaplara göre iklim elemanlarından özellikle yağış ve rüzgâr faktörünün elde edilen ürün miktarı üzerinde etkili olduğu anlaşılmaktadır. Elde edilen bulgulara göre bitki örtüsünü etkilediğinden dolayı yağışın fazla olduğu dönemlerde evrim artarken, yağışın az olduğu dönemlerde ise verim azalmaktadır. Yine yağışın türü ise elde edilen ürün miktarı üzerinde etkili olan bir diğer faktördür. Dolu yağışının etkili olduğu dönemlerde gerek bitki örtüsünün tahrip edilmesi gerekse arılara zarar vermesinden dolayı verim azalmaktadır. Yine arıcılık yapan bölgede etkili olan kuvvetli rüzgârlardan da hem 
bitki örtüsü hem de arılar olumsuz etkilenmekte ve bu durum elde edilen verimin düşmesine yol açmaktadır.

Sivas Ili'nde Arıcılık Ile Uğrașan Bireylerin Materyalleri Temin Etme Konusunda Karşıllaștıkları Sorunlar Ve Materyal Temin Etme Yerleri

Araştırma sahasında görüşme yapılan bal üreticilerinden alınan cevaplara göre materyal temin etme konusunda sıkıntı yaşanmamakla birlikte, üreticilerin materyalleri bu alanda faaliyet gösteren kurum veya birliklerden ziyade özel kuruluşlardan temin ettiği görülmektedir (Tablo 10). Bu durum arıc1lık faaliyetinde il genelinde kurumsallaşmanın olmadığını tam olarak oturmadığını göstermektedir.

Tablo 10. Sivas İli'nde Arıcıık Ille Uğraşan Bireylerin Materyal Temin Etme Yerleri.

\begin{tabular}{lcccccccc}
\hline $\begin{array}{l}\text { Temin } \\
\text { edilen } \\
\text { yer }\end{array}$ & Divriği & Gürün & İmranlı & Koyulhisar & Yıldızeli & Zara & $\begin{array}{c}\text { Toplam } \\
\text { (Kişi) }\end{array}$ & $\begin{array}{c}\text { Yüzde } \\
\text { (\%) }\end{array}$ \\
\hline $\begin{array}{l}\text { Esnaf } \\
\text { Tarım }\end{array}$ & 30 & 19 & 23 & 18 & 17 & 28 & $\mathbf{1 3 5}$ & $\mathbf{8 2 , 4}$ \\
$\begin{array}{l}\text { Kredi } \\
\text { Koop. }\end{array}$ & 3 & 6 & 2 & 8 & 4 & 6 & $\mathbf{3 1}$ & $\mathbf{1 7 , 6}$ \\
\hline $\begin{array}{l}\text { Toplam } \\
\text { (Kişi) }\end{array}$ & $\mathbf{3 3}$ & $\mathbf{2 5}$ & $\mathbf{2 5}$ & $\mathbf{2 6}$ & $\mathbf{2 1}$ & $\mathbf{3 4}$ & $\mathbf{1 6 4}$ & $\mathbf{1 0 0}$ \\
\hline
\end{tabular}

Tablo 10' da da görüldüğü gibi görüşme yapılan bal üreticilerin büyük bir çoğunluğu $(\% 82,4)$ arıc1lık faaliyeti ile ilgili olan materyalleri bu alanda faaliyet gösteren esnaflardan karşılarken, çok az bir kısmı $(\% 17,6)$ ise bulundukları yörede yer alan tarım kredi kooperatiflerinden temin etmektedirler. İlçeler bazında da tüm ilçelerde materyalleri esnaflardan karşılayanların sayısı tarım kredi kooperatiflerinden karşılayanlardan oldukça fazladır.

Sivas Ili'’nde Arıcılık Ille Uğraşan Bireylerin Bu Faaliyeti Yürüttüğü Alanın Iklim Özellikleri Hakkındaki Görüşleri

Sivas İli genel olarak "İç Anadolu Karasal İklim Tipi"nin etkisi altındadır. Araştırma sahasında görüşme yapılan bal üreticilerinin \% 70,7'si (116 kişi) ilde hâkim olan iklim şartlarını arıcılık faaliyetleri için elverişli olarak görürken, \% 29'2'si ise ilde (48) kişi elverişsiz olarak görmektedir (Tablo 11). 
Tablo 11. Sivas Ili'nde Arıcılık Ile Uğraşan Bireylerin Bu Faaliyeti Yürüttüğü Alanın İklim Özellikleri Hakkındaki Görüşleri.

\begin{tabular}{ccccccccc}
\hline İklim & Divriği & Gürün & İmranlı & Koyulhisar & Yıldızeli & Zara & Toplam & $\begin{array}{c}\text { Yüzde } \\
\text { (\%) }\end{array}$ \\
\hline Elverişli & 26 & 19 & 15 & 22 & 12 & 22 & $\mathbf{1 1 6}$ & $\mathbf{7 0 , 7}$ \\
Elverişsiz & 7 & 6 & 10 & 4 & 9 & 12 & $\mathbf{4 8}$ & $\mathbf{2 9 , 3}$ \\
\hline $\begin{array}{c}\text { Toplam } \\
\text { (Kişi) }\end{array}$ & $\mathbf{3 3}$ & $\mathbf{2 5}$ & $\mathbf{2 5}$ & $\mathbf{2 6}$ & $\mathbf{2 1}$ & $\mathbf{4 4}$ & $\mathbf{1 6 4}$ & $\mathbf{1 0 0}$ \\
\hline
\end{tabular}

Tüm ilçelerdeki arıcılık faaliyetleri ile uğraşan bireylerden iklim şartlarını elverişli olarak görenlerin sayısı elverişsiz görenlerin sayısından fazla iken, Zara ve İmranlı ilçelerinde iklim şartlarını elverişsiz görenlerin sayısının fazla olduğu görülmektedir. Bu durum Zara ve bu ilçeye yakın olan İmranlı ilçesinde sıcaklık ortalamalarının diğer ilçelere göre düşük olmasından kaynaklanmaktadır. Divriği, Gürün ve Koyulhisar'da ise iklim şartlarını elverişsiz görenlerin sayısının düşük olduğu dikkat çekmektedir ki sıcaklık ortalamaları dağılışı incelendiğinde il genelinde sıcaklık en yüksek sıcaklık ortalamalarının bu ilçelerde veya bu ilçelere yakın istasyonlarda olduğu görülür. Bu durum ildeki bal üreticilerinin bu faaliyeti yürüttükleri yörenin iklim şartları hakkında yeterli bilgiye sahip olduklarını ortaya koymaktadır.

Arıcılık Ile Uğraşan Fertlerin Iklim Koșullarının Olumsuz Seyrettiği Dönemde Karșılaștıkları Sorunlar ve Bunlarla Mücadele Yöntemleri

İklim faaliyetleri yeryüzünde insanlar tarafından yürütülen hemen hemen tüm faaliyetler üzerinde etkili olmaktadır. İklim şartlarının faaliyetler üzerindeki bu etkisi gelişmiş olan ülkelerde daha az görülürken veya hissedilirken, gelişmekte olan veya geliş̧memiş toplumlarda ise daha fazla görülmektedir. Çünkü bu toplumlarda yürütülen faaliyetler büyük oranda doğal şartlara bağlı olarak yapılmaktadır.

İklim şartlarının üzerinde en fazla etkili olduğu faaliyetlerden birisi de tarım ve hayvanc1lıktır. Dolaysıyla hayvancılık faaliyetlerinin bir türü olan arıc1lık da büyük oranda iklim şartlarının ekişi altında şekillenmektedir. Araştırma sahasında görüşme yapılan bal üreticilerinin iklim şartlarının elverişsiz olduğu dönemlerde karşılaştığı sorunlar verim düşüklüğü ve arı ölümleridir (Tablo. 12).

Arıcılıklar uğraşan bireylerden alınan cevaplara göre araştırma sahasında en fazla karşılaşılan problem verim düşüklüğüdür $(\% 64)$. Bu problem ilçelerin tümünde yüksek oranda görülmektedir. Verim düşüklüğünden sonra karşılaşılan bir diğer önemli problem ise arı ölümleridir (\% 36). Bal üreticilerinin ifadelerine göre özellikle zamansız bir şekilde görülen dolu şeklinde yağışlar arı ölümleri üzerinde büyük etkiye sahiptir. 
Tablo 12. Sivas İli'nde Arıcılık İle Uğraşan Bireylerin İklim Şartlarının Elverişsiz Olduğu Dönemlerde Karşılaştıkları Sorunlar.

\begin{tabular}{lcccccccc}
\hline Sorunlar & Divriği & Gürün & İmranlı & Koyulhisar & Yıldızeli & Zara & $\begin{array}{c}\text { Toplam } \\
\text { (Cevap) }\end{array}$ & $\begin{array}{c}\text { Yüzde } \\
\text { (\%) }\end{array}$ \\
\hline $\begin{array}{l}\text { Verim } \\
\text { Düşüklüğü }\end{array}$ & 33 & 25 & 24 & 26 & 20 & 32 & $\mathbf{1 6 0}$ & $\mathbf{6 4}$ \\
$\begin{array}{l}\text { Arı } \\
\text { Ölümleri }\end{array}$ & 20 & 15 & 16 & 13 & 14 & 12 & $\mathbf{9 0}$ & $\mathbf{3 6}$ \\
\hline $\begin{array}{l}\text { Toplam } \\
\text { (Cevap) }\end{array}$ & $\mathbf{5 3}$ & $\mathbf{4 0}$ & $\mathbf{4 0}$ & $\mathbf{3 9}$ & $\mathbf{3 4}$ & $\mathbf{4 4}$ & $\mathbf{2 5 0}$ & $\mathbf{1 0 0}$ \\
\hline
\end{tabular}

İklim şartlarından kaynaklı bu problemlerin giderilmesine veya etkilerinin en aza indirgenmesine yönelik olarak ise bal üreticilerinin yaptığ mücadelenin olmadığı araştırma sahasında yapılan görüşmeler sonucunda belirlenmiştir.

\section{Sivas Ili’nde Bal Üreticilerinin Arıcılık Faaliyetini Yürüttüŭü Sahaların} Yeryüzü Șekilleri ve Bu Faaliyete Etkisi Hakkındaki Görüşleri

Araştırma sahası olan Sivas İli dağlık ve engebeli bir topografyaya sahiptir. Araştırma sahasında yapılan saha çalışmalarında ve bal üreticileri ile yapılan görüşmeler neticesinde üreticilerin bu faaliyeti daha çok dağlık ve engebeli sahalarda yürüttükleri belirlenmiştir

Görüşme yapılan bal üreticilerinin büyük bir çoğunluğu $(\% 79,8)$ bu faaliyeti dağlık ve engebeli sahalarda yürütürken, az bir kısmı ise (\% 20,2) düzlük ve ovalık sahalarda bu faaliyeti yürütmektedir (Tablo 13).

Tablo 13. Araştırma Sahasında Arıcılık Faaliyetlerinin Yürütüldüğü Yeryüzü Şekilleri.

\begin{tabular}{ccccccccc}
\hline $\begin{array}{l}\text { Yeryüzü } \\
\text { Şekilleri }\end{array}$ & Divriği & Gürün & İmranlı & Koyulhisar & Yıldızeli & Zara & $\begin{array}{c}\text { Toplam } \\
\text { (Kişi) }\end{array}$ & $\begin{array}{c}\text { Yüzde } \\
(\%)\end{array}$ \\
\hline Dağlık & 28 & 19 & 20 & 18 & 17 & 29 & 131 & 79,8 \\
Ovalık & 5 & 6 & 5 & 8 & 4 & 5 & 33 & 20,2 \\
\hline Toplam & $\mathbf{3 3}$ & $\mathbf{2 5}$ & $\mathbf{2 5}$ & $\mathbf{2 6}$ & $\mathbf{2 1}$ & $\mathbf{3 4}$ & $\mathbf{1 6 4}$ & $\mathbf{1 0 0}$
\end{tabular}

$$
\text { (Kişi) }
$$

Tablo 13'te görüldüğü gibi saha gezisi yapılan tüm ilçelerde bal üreticilerinin dağlık ve engebeli sahaları tercih ettikleri görülmektedir. $\mathrm{Bu}$ tercihte yörenin topografik yapısı yanında üreticilerin tarım ve hayvan otlatmanın yapıldığ uzak sahaları arıcılık için daha uygun görmeleri de etkili olmuştur. Ayrıca saha çalışmalarında yapılan görüşmeler neticesinde yüksek kesimlerde çiçeklenme döneminin geç olması ve bitkilerin yeşil kalma süresinin alçak kesimlere göre daha uzun olması da bu tercihte etkili olduğu belirlenmiştir.

Araştırma sahasında görüşme yapılan bal üreticilerinin \% 92,1'i arıcılık faaliyeti açısından yürüttükleri yörenin topografyasını bu faaliyeti olumlu etkilediğini düşünürken, \% 7,9'u ise topografyanın iklim, ulaşım ve kolonilerini konumlandıracak alanın yetersizliğine olan etkilerinden dolayı topografyanın bu faaliyeti olumsuz etkilediğini düşünmektedirler (Şekil 3). Tüm ilçelerde 
topografyanın arıc1lık faaliyetini olumlu etkilediğini düşünenlerin sayısı, olumsuz etkilediğini düşünenlerin sayısından fazladır.

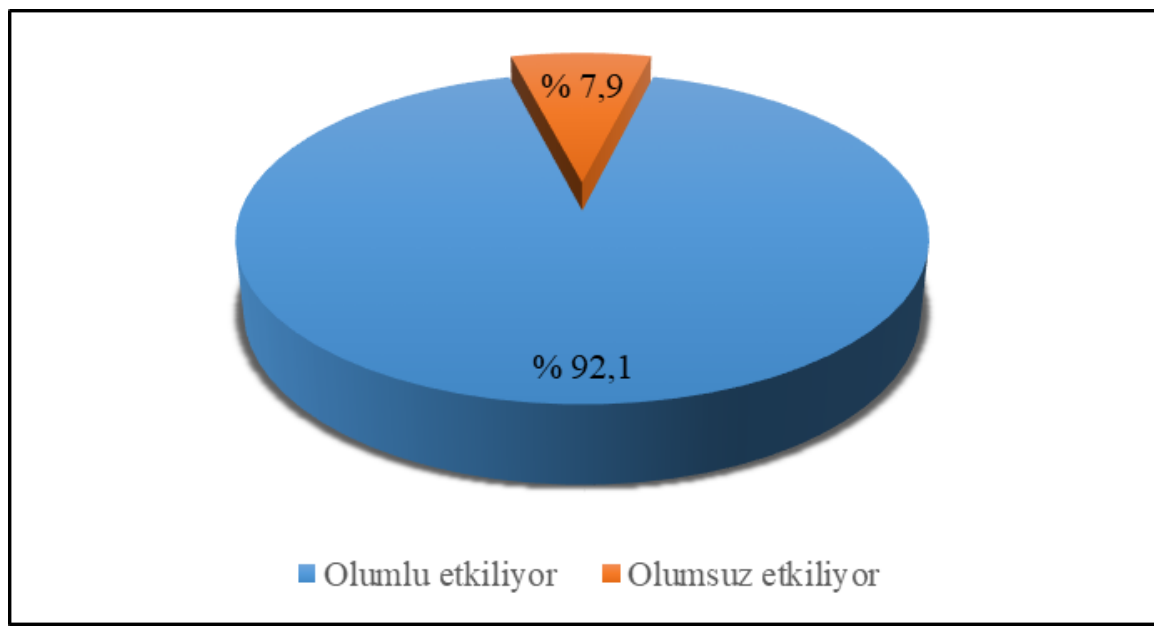

Şekil 3. Araştırma Sahasındaki Bal Üreticilerinin Yeryüzü Şekillerinin Arıcılık Faaliyetine Olan Etkisi İle İlgili Görüşleri.

\section{Arıcılık Ille Uğrașan Bireylerin Bu Faaliyeti Yürüttüğü Alanın Bitki Özellikleri Hakkında Bilgi Düzeyleri}

Arıcılık faaliyetlerinin yapıldığ yörenin bitki özellikleri ile bu faaliyet arasında sıkı bir ilişki vardır. Her şeyden önce bal üretimi bitki özlerinden gerçekleştirildiği için, yörenin sahip olduğu bitki örtüsünün çeşitliliği, çiçeklenme dönemi arıc1lı faaliyetlerinde verim açısından oldukça önem arz etmektedir. Dolaysıyla arıcılıkla uğraşan bireylerin o yöredeki bitki örtüsü hakkındaki bitki çeşitliliği, çiçeklenme dönemleri, ballı bitkiler grubunda yer alan türler vb. gibi bilgileri elde edilecek verim açısından büyük öneme sahiptir.

Sivas İli karasal iklim şartlarının etkisi altında olduğundan dolayı yörenin hâkim bitki örtüsü bozkırdır. Ayrıca ilin Karadeniz kesimine komşu olan yöreleri ile yüksek kesimlerinde orman formasyonu içerisinde yer alan ağaç türleri de yer almaktadır.

Çalışma sahasında bal üreticilerinin vermiş olduğu cevaplara göre arıc1ık faaliyetlerinin yürütüldüğü alanlarda bozkır bitkisi türleri yaygındır. Çakırdikeni, geven, kekik bal üreticilerinin örnek verdiği bozkır bitkisi türlerindendir. Bunun yanında ağaç veya ağaççıklar grubu içerisinde yer alan akasya ile ekim-dikime bağlı faaliyetlerden elde edilen yonca, korunga, nohut ve ayçiçeği gibi bitkiler de bal üreticileri tarafindan yörenin bitki özelliklerine örnek olarak verilmiştir (Tablo 14). Bal üretiminde bu bitki türlerinden de yararlanıldığı için bal üreticileri tarafından yörenin bitki örtüsü özelliklerine örnek olarak verilmiştir. 
Tablo 14. Sivas Ili'nde Arıclık İle Uğraşan Bireylerin Yörenin Bitki Örtüsüne Verdikleri Örnekler.

\begin{tabular}{lcccccccc}
\hline $\begin{array}{l}\text { Bitki } \\
\text { Türü }\end{array}$ & Divriği & Gürün & İmranlı & Koyulhisar & Yıldızeli & Zara & $\begin{array}{c}\text { Toplam } \\
\text { (Cevap) }\end{array}$ & $\begin{array}{c}\text { Yüzde } \\
\text { (\%) }\end{array}$ \\
\hline $\begin{array}{l}\text { Çakır } \\
\text { Dikeni }\end{array}$ & 10 & 5 & 7 & 5 & 6 & 8 & $\mathbf{4 1}$ & $\mathbf{1 3 , 3}$ \\
Geven & 13 & 12 & 11 & 15 & 18 & 20 & $\mathbf{8 9}$ & $\mathbf{2 9 , 1}$ \\
Kekik & 9 & 13 & 14 & 17 & 15 & 18 & $\mathbf{8 6}$ & $\mathbf{2 8 , 2}$ \\
Akasya & 3 & & & 3 & 1 & 4 & $\mathbf{1 1}$ & $\mathbf{3 , 6}$ \\
Yonca & 6 & 5 & 4 & 4 & 1 & 4 & $\mathbf{2 4}$ & $\mathbf{7 , 8}$ \\
Korunga & 8 & 9 & 3 & 5 & 1 & 3 & $\mathbf{2 9}$ & $\mathbf{9 , 4}$ \\
$\begin{array}{l}\text { Nohut } \\
\begin{array}{l}\text { Ay çiceği } \\
\text { Ispir }\end{array}\end{array}$ & 2 & 2 & & 2 & & 4 & $\mathbf{1 0}$ & $\mathbf{3 , 3}$ \\
\hline $\begin{array}{l}\text { Toplam } \\
\text { (Cevap) }\end{array}$ & $\mathbf{5 5}$ & $\mathbf{4 6}$ & $\mathbf{4 2}$ & $\mathbf{5 5}$ & $\mathbf{4 3}$ & $\mathbf{6 5}$ & $\mathbf{3 0 6}$ & $\mathbf{1 0 0}$ \\
\hline
\end{tabular}

Bal üreticilerinin yöredeki bitki türlerine en fazla örnek verdiği bitkiler içerisinde en yüksek oranı $\% 29,1$ ile geven bitkisi olup, bu bitki türünü \% 28,2 ile kekik ve ve 13,3 ile çakırdikeni oluşturmaktadır. $\mathrm{Bu}$ üç bitki türünün oranı verilen cevapların \% 70,6'sını oluşturmaktadır ve saha çalışmasını yapıldığı tüm ilçelerde bal üreticilerinin en fazla örnek verdiği türlerdendir. Araş̧ırma sahasında bu bitki türleri yaygın olarak görüldüğünden bal üreticilerinin verdiği örnekler arasında en yüksek oranı oluşturmuştur. Bu bitki türlerinden başka yonca $(\% 9,4)$ ve akasya $(\%$ 7,8 )'da verilen cevaplar içerisinde oranı yüksek olan bitki türlerindendir (Tablo $14)$.

\section{Sivas Ili’’nde Arıcılık Yapılan Yörelerde Yürütülen Diğer Ekonomik Faaliyetler}

Sivas İli ekonomisi ağırlıklı olarak tarım ve hayvancılık faaliyetlerine dayanmaktadır. Ayrıca ilde madencilik de yine yürütülen önemli ekonomik faaliyet türlerinden biridir. Bal üreticileri yapılan görüşmelerde de bal üreticileri yörede yürütülen ekonomik faaliyet hakkında bu alanda örnek vermişlerdir (Tablo 15).

Tablo 15. Arıcılık Yapılan Yörelerde Yürütülen Diğer Ekonomik Faaliyetler.

\begin{tabular}{lcccccccc}
\hline $\begin{array}{l}\text { Yürütülen } \\
\text { Ekonomik } \\
\text { Faaliyetler }\end{array}$ & Divriği & Gürün & İmranlı & Koyulhisar & Yıldızeli & Zara & $\begin{array}{c}\text { Toplam } \\
\text { (Cevap) }\end{array}$ & $\begin{array}{c}\text { Yüzde } \\
\text { (\%) }\end{array}$ \\
\hline $\begin{array}{l}\text { Tarımsal } \\
\text { Faaliyetler } \\
\text { Hayvancılık }\end{array}$ & 15 & 25 & 18 & 15 & 15 & 22 & $\mathbf{1 1 0}$ & $\mathbf{4 4 , 1}$ \\
Madencilik & 7 & 18 & 23 & 20 & 17 & 29 & $\mathbf{1 3 2}$ & $\mathbf{5 3 , 1}$ \\
\hline $\begin{array}{l}\text { Toplam } \\
\text { (Cevap) }\end{array}$ & $\mathbf{4 7}$ & $\mathbf{4 3}$ & $\mathbf{4 1}$ & $\mathbf{3 5}$ & $\mathbf{3 2}$ & $\mathbf{5 1}$ & $\mathbf{2 4 9}$ & $\mathbf{1 0 0}$ \\
\hline
\end{tabular}

Bal üreticilerin verdikleri cevaplara göre arıcılık yapılan yörelerde ağırlıklı olarak hayvancilık faaliyetleri yapılmaktadır. Verilen cevapların \% 53,1'i bu faaliyet ile ilgilidir. Hayvancılıktan sonra yapılan bir diğer faaliyet türü ise tarımdır ( $\% 44,1)$. İlçeler bazında ise bal üreticilerinin vermiş oldukları cevaplara göre arıcılık 
faaliyetlerinin yürütüldüğü ilçelerden Divriği, İmranlı, Koyulhisar, Yıldızeli ve Zara ilçelerinde hayvancılık faaliyetleri tarımsal faaliyetlere göre daha çok ön plana çıkarken, sadece Gürün İlçesi'nde tarımsal faaliyetler hayvancılık faaliyetlerine göre ön plana çıkmaktadır. Bu iki faaliyetten başka sadece Divriği İlçesi'nde madencilik faaliyeti de arıcılık faaliyeti yürütülen bölgede yapılmaktadır (Tablo 14).

Arıcılık yapılan yörelerde veya yörelere yakın yerlerde yürütülen ekonomik faaliyetler arıc1lık faaliyetlerini olumlu veya olumsuz olarak etkileyebilmektedir. Örneğin tarımsal faaliyetler sırasında kullanılan zirai ilaçlar arıları olumsuz etkilerken, yetiştirilen ürün türleri ise çeşitliliğe neden olacağından arıcılığı olumlu etkilemektedir. Hayvancılık yapılan yörelerde aşırı veya erken otlatma bitki örtüsünün tahribine neden olacağından arıcılık faaliyetleri üzerinde olumsuz etkiye sahiptir.

Araştırma sahasında görüşme yapılan bal üreticilerinin \% 87,8'inin yörede yürütülen ekonomik faaliyetlerin arıcılığı olumlu etkilediğini düşünürken, \% 12,2'si ise olumsuz etkilediğini düşünmektedir (Şekil 4).

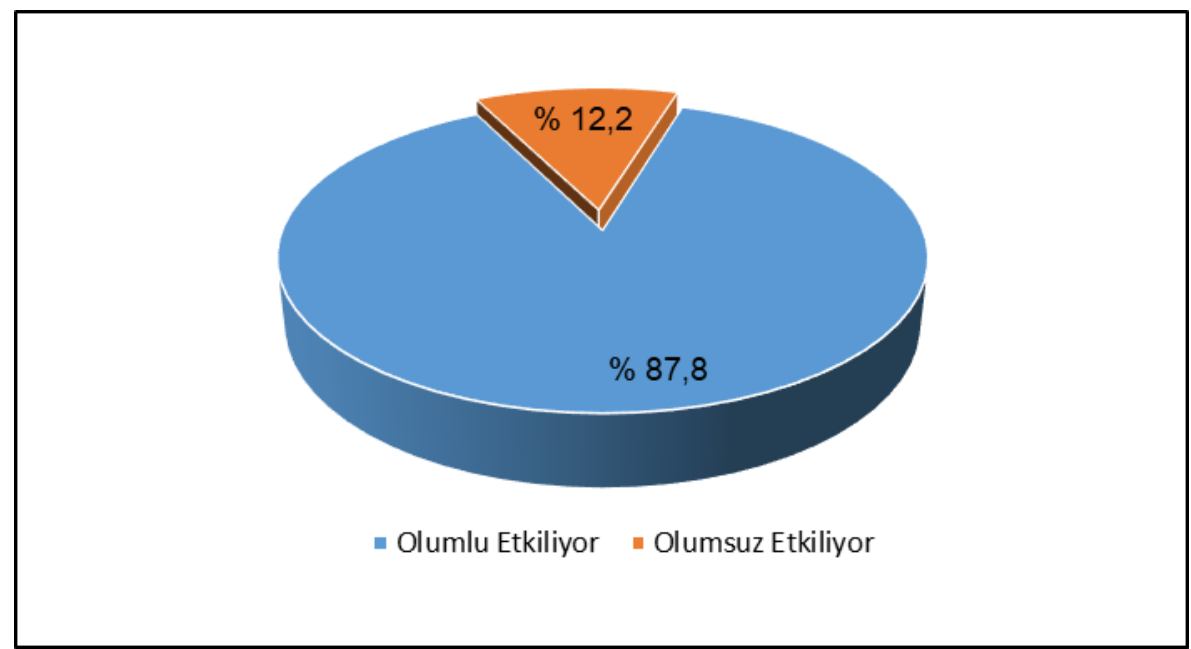

Şekil 4. Bal Üreticilerinin Yörede Yürütülen Ekonomik Faaliyetlerin Arıclık Üzerindeki Etkisi Hakkındaki Görüşleri.

Yörede yürütülen ekonomik faaliyetlerin arıcılığı olumlu etkilediği düşünenlerin sayısının fazla olmasında bu üreticilerin tarım, hayvancilık veya madencilik gibi faaliyetlerin yürütüldüğü sahaların uzağında bulunması etkili olmuştur. Ayrıca bu kişiler tarımsal faaliyetlerin bitki çeșitliliğinin arttırdığını, hayvancılığın ise bitki örtüsünün gelişimi üzerinde olumlu etkiye sahip olduğunu düşünmektedirler. Yörede yürütülen ekonomik faaliyetlerin arıcıllğı olumsuz etkilediğini düşünenler ise tarımsal faaliyetlerde kullanılan zirai ilaçların arı ölümlerine ve bal kalitesinin düşmesine neden olduğunu, otlatma ile bitki örtüsünün tahrip olduğunu, özellikle küçükbaş hayvancılık yapılan yerlerde otlatma alanlarına arıların girmediğini, madencilik faaliyetlerinin bitki örtüsünü tahrip ettiğini, maden çıkarımı sırasında 
ortaya çıkan gürültü, toz ve dumanın arıları olumsuz etkilediğini ifade etmektedirler.

Arıcılık İle Uğrașan Bireylerin Bu Faaliyeti Yürütürken Karșılaștıkları Hastalıklar ve Bunlarla Mücadele Yöntemleri

Çalışma sahasında bal üreticilerinin vermiş oldukları cevaplara göre arıcılık faaliyetini yürütürken karşılaştıkları hastalık türleri sırasıyla \% 43,3 varooa, \% 33,5 Amerikan yavru çürüklüğü, \% 19,2 lösema ve \% 4 arı bitidir (Tablo 16).

Tablo 16. Sivas İli’ndeki Bal Üreticilerinin Karşılaştığı Arı Hastalıkları.

\begin{tabular}{lcccccccc}
\hline Hastalıklar & Divriği & Gürün & İmranlı & Koyulhisar & Yıldızeli & Zara & $\begin{array}{c}\text { Toplam } \\
\text { (Cevap) }\end{array}$ & $\begin{array}{c}\text { Yüzde } \\
(\%)\end{array}$ \\
\hline Varooa & 19 & 15 & 13 & 19 & 17 & 22 & $\mathbf{1 0 5}$ & $\mathbf{4 3 . 3}$ \\
$\begin{array}{l}\text { Amerikan } \\
\begin{array}{l}\text { Yavru } \\
\text { Çürüklüğü }\end{array}\end{array}$ & 20 & 12 & 12 & 13 & 9 & 16 & $\mathbf{8 2}$ & $\mathbf{3 3 . 5}$ \\
$\begin{array}{l}\text { Nosema } \\
\text { Arı Biti }\end{array}$ & 10 & 9 & 8 & 5 & 7 & 8 & $\mathbf{4 7}$ & $\mathbf{1 9 . 2}$ \\
\hline $\begin{array}{l}\text { Toplam } \\
\text { (Cevap) }\end{array}$ & 2 & 2 & 1 & 1 & 2 & 2 & $\mathbf{1 0}$ & $\mathbf{4 . 0}$ \\
\hline
\end{tabular}

"Bir parazit türü olan varroa (Varroa destructor) hem ergin arlar hem de gelişmekte olan larva ve pupalar üzerinde yaşamını sürdürebildiğinden bal arısı kolonilerine büyük zararlar vermekte, arı kolonilerinin canlılığını olumsuz yönde etkilemekte, kolonilerde genç arı sayısının azalmasına, koloni içi düzenin bozulmasına ve önlem alınmadı̆̆ takdirde ise 3-4 yıl içerisinde kolonilerin tamamen yok olmasına neden olmaktadır" (Cengiz ve diğerleri, 2010, s.50). "Bacillus Larva adındaki bir bakterinin sebep olduğu Amerikan yavru çürüklüğ̈̈ (AYÇ) hastalı̆̆ ise arı hastalıkları içerisinde en bulaşıcısı olup, enfekte olmuş gıdaların ağız yoluyla alınması ile arllara bulaşan bu hastalık bilgisiz ve bilinçsiz arıcının etmenin bulaştığl alet ve ekipmanlarla çalışması, sterilize edilmemişs temel petekler kullanması, hastalıklı koloniden sağlam kolonilere çerçeve aktarılması, kolonilerin bölme ve birleştirilmesi, hastalıklı bulaşık eski kovanların kullanılması hastalığın yayılmasını hızlandırır”" (Amerikan Yavru Çürüklüğü, 2015).

Bal üreticilerinin arılarda karşılaştı̆̆ı bir diğer hastalık ise nosemadır. Aşırı nem, yetersiz havalandırma, yetersiz beslenme, koloni kontrolleri sırasında ergin arıların ezilmesi, ezilen arıların dışarı atılmasıyla sağlıklı arıların bunlarla teması gibi nedenlere bağlı olarak ergin arılarda görülen bu hastalık işçi arının ömrünü kısaltarak verimin azalmasına neden olur (Nosema Hastalığı, 2015).

Arı hastalıkları koloni kayıplarına varan kayıplara neden olarak verimin azalmasına neden olur. Bundan dolayı hastalıklarla mücadele arıcılıkta oldukça büyük bir öneme sahiptir. Bal üreticileriyle yapılan görüşmelere göre üreticiler hastalıklarla mücadelede en çok ilaçlama yöntemine $(\% 91,4)$ baş vurmaktadır. Sahada görüşme yapılan üreticilerin neredeyse tamına yakını hastalıklarla mücadelede bu yönteme başvurmaktadırlar. İlaçlamadan başka kireç $(\% 7,3)$ ve tütsü $(\% 1,2)$ de üreticilerin tercih ettiği bir diğer mücadele yöntemidir (Tablo 17). 
Tablo 17. Sivas Ill'ndeki Bal Üreticilerinin Arı Hastalıklarıyla Mücadele Yöntemleri.

\begin{tabular}{|c|c|c|c|c|c|c|c|c|}
\hline $\begin{array}{l}\text { Mücadele } \\
\text { Yöntemleri }\end{array}$ & Divriği & Gürün & İmranlı & Koyulhisr & Yıldızeli & Zara & $\begin{array}{l}\text { Toplam } \\
\text { (Cevap) }\end{array}$ & $\begin{array}{c}\text { Yüzde } \\
(\%)\end{array}$ \\
\hline İlaçlama & 32 & 22 & 20 & 24 & 20 & 32 & 150 & 91.5 \\
\hline Kirec & 1 & 3 & 4 & 1 & 1 & 2 & 12 & 7.3 \\
\hline Tütsü & & & 1 & 1 & & & 2 & 1.2 \\
\hline $\begin{array}{l}\text { Toplam } \\
\text { (Cevap) }\end{array}$ & 35 & & & & & & 164 & 100 \\
\hline
\end{tabular}

Sivas Ili’nde Aracılıkla Uğraşan Fertlerin Bu Faaliyetten Elde Ettikleri Ürünleri Pazarlama Ille Illgili Sorunları

Ekonomik faaliyetlerde pazarlama arz-talep dengesini sağladığından ve üretilen ürünün tüketilebilmesine olanak sağladığından dolayı önemli bir yere sahiptir. Üretimin gerçekleşmesi büyük oranda geniş bir tüketici kitlesine ve dolaysıyla bu tüketici kitlesine ulaşılabilirliği sağlayacak olan pazarlama olanaklarına bağlıdır.

Araştırma sahasına görüşme yapılan bal üreticilerinin büyük bir çoğunluğu $(84,2)$ ürettikleri arıcılık ile ilgili ürünlerinin pazarlama sorunun olmadığını belirtirken, (Şekil 3) az bir kısmı ise (\% 15,8) pazarlama sorunlarının olduğunu belirtmişlerdir (Şekil 5).

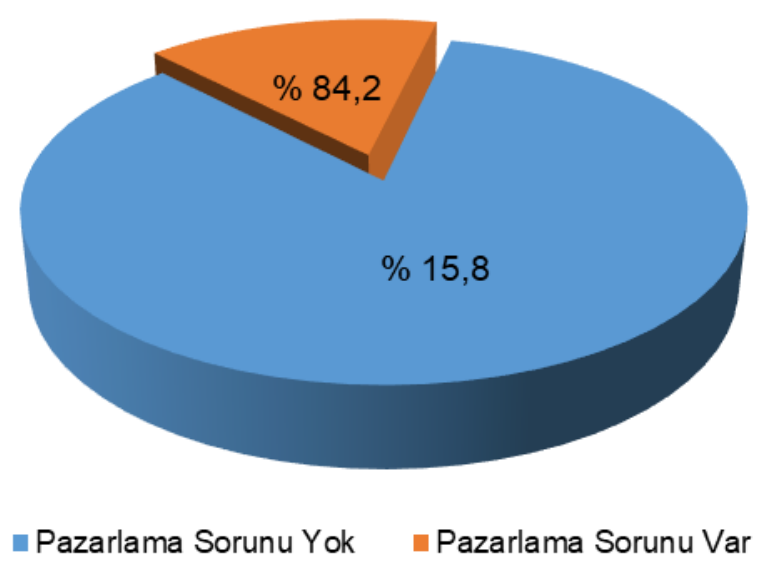

Şekil 5.Görüşme Yapılan Bal Üreticilerinin Pazarlamaya Yönelik Görüşleri.

Araştırma sahasına arıcılık alanında faaliyet gösteren kooperatif türü kurum veya kuruluşlar bulunmamasına rağmen üreticilerin pazarlama sorunu yaşamamaları, balın gida maddesi olarak tüketimde önemli bir yere sahip olmasından dolayı üreticilerin ürünlerini küçük işletmelere veya şahsi olarak pazarlayabilmesinden kaynaklanmaktadır. Gerçekten de görüşme yapılan bal üreticilerinin büyük bir çoğunluğu $(\% 79,8)$ ürünlerini market veya arıcılık ile ilgili materyalleri temin ettikleri toptancılara toptan pazarladıklarını belirtmişlerdir (Şekil 6). Aslında bu durum her ne kadar pazarlama sorununu çözse de fiyatlandırmada ortak bir fiyatın belirlenmemesinden dolayı üreticilerin gelir kaybına neden olmaktadır. 


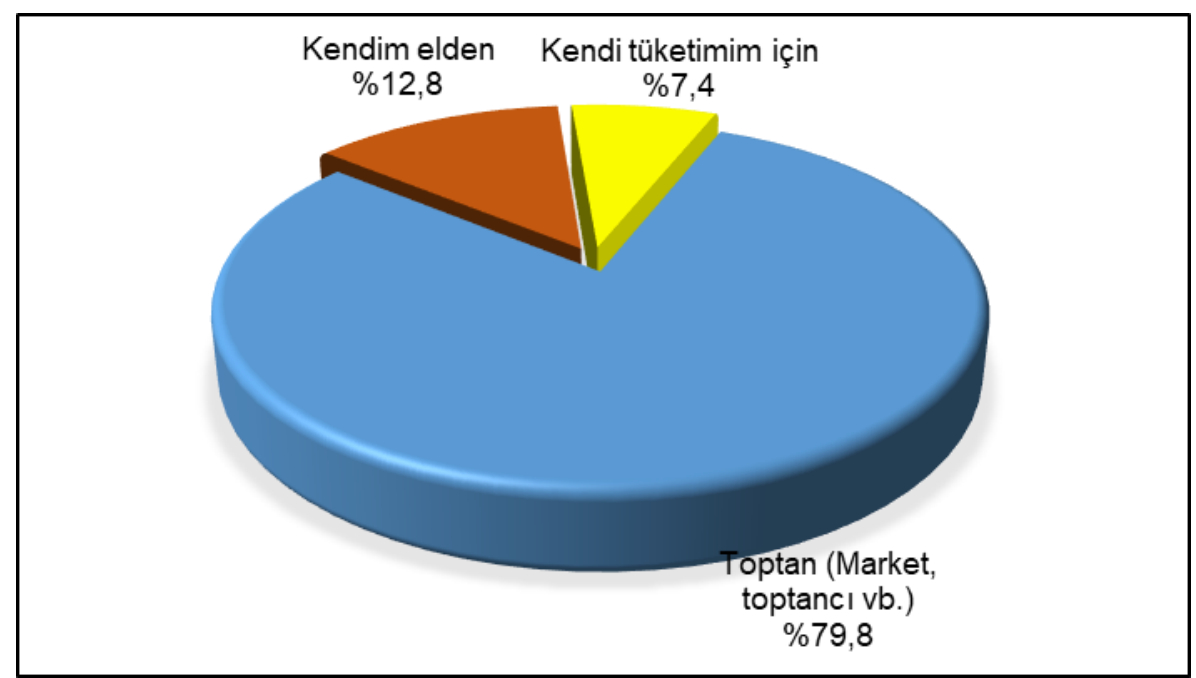

Şekil 6. Görüşme Yapılan Bal Üreticilerinin Ürünlerini Pazarlama Yöntemleri

Bunun dişında üreticilerin \% 12,8'i ürettikleri ürünleri kendi imkânlarıyla pazarlarken \% 7,4'ü ise kendileri tükettikleri için ürünlerin pazarlamasını yapmadıklarını belirtmişlerdir.

\section{Tartışma ve Sonuç}

Araştırma sahasında görüşme yapılan bal üreticilerinin \% 57,4’ü yerli arıcı, \% 22,1 'i yöre dışından gelen ve \% 20,1'i ise yöre dışına giden gezgin arıcılardan oluşmaktadır. Dolayısıyla görüşme yapılan yaklaşık her beş kişiden biri bu faaliyeti gezgin arıcı olarak yapmaktadır. Ancak hem yöre dışından gelen gezgin arıcıların hem de yerli arıcıların görüşlerinden ve saha gezilerinden elde edilen izlenimlere göre yöre dışından gelen gezgin arıcılar için yer problemi önemli bir sorundur. Yöre dışından gelen gezgin arıcılar bir plan dâhilinde bu faaliyeti yürütecekleri sahalara konumlandırılmadığından bu durum yer sorununu ortaya çıkarmakta, arılar arasında dışardan getirilmesi muhtemel arı hastalıkların yayılmasına neden olmaktadir.

Araştırma sahasında görüşme yapılan bal üreticilerinin yaklaşık \% 53'ü nün sahip olduğu kovan sayısı 1-50 adet arasında olup, bunun \% 42,5'inin sahip olduğu kovan sayısı 100 âdetin altındadır. Bu durum ildeki arıcılık faaliyetlerinin küçük işletmeler şeklinde yürütüldüğünü ve ilin sahip olduğu potansiyelinin yeterince kullanılamadığını göstermektedir.

Araştırma sahasında hüküm süren iklim koşulları arıcılık faaliyetleri açısından uygun olmakla beraber özellikle hava şartlarında meydana gelen ani değişimler ve kurak devrenin yaşanması verim üzerinde büyük etkiye sahiptir. Görüşme yapılan bal üreticilerinin tamamı verimde meydana gelen değişmelerin tek sebebini iklim ve hava şartlarına bağlamaktadırlar ve hava şartlarının elverişsiz olduğu dönemlerde herhangi bir tedbir almamaktadırlar. Bu durum bal üreticilerinin hava 
koşullarının seyri hakkında yeterli bilgiye sahip olmadığını ortaya koyduğu gibi, olumsuz koşullarda ne gibi tedbirler alacakları hakkında bilgi birikimine sahip olmadıklarını ortaya koymaktadır.

Araştırma sahasında üreticilerin arıcılık ile ilgili materyalleri karşılama problemi bulunmamakla birlikte, üreticilerin büyük bir çoğunluğu $(\% 82,4)$ gerekli materyalleri esnaflardan temin etmektedirler. Bu durum ilde arıcılık faaliyetlerin organize bir şekilde yürütülmediğini göstermektedir.

Görüşme yapılan bal üreticileri bu faaliyeti yürüttüğü alanın bitki örtüsü özellikleri ilgili olarak çakırdikeni, geven, kekik, akasya, yonca, korunga, nohut, ayçiçeği ve ispir olmak üzere sadece dokuz tane örnek verdikleri, verilen örneklerin ise daha çok kekik ve geven üzerinde yoğunlaşttğı tespit edilmiştir. Oysa araştırma sahasında bu bitki türlerinin dışında başka doğal bitki türleri bulunmakta olup, özellikle de ağaç türlerine ait hiçbir cevap görüşme yapılan bal üreticilerinden alınamamıştır.

Araştırma sahasında arıcılık faaliyetinde elde edilen ürünlerin pazarlanma sorunu olmamasına rağmen, üreticilerin yaklaşı \% 80'i ürettikleri ürünleri market veya toptancılara pazarlarken, \% 13'ü ise kendi imkânları ile pazarlamaktadırlar. Bu durum özellikle fiyatlandırmada belirli bir ölçüt olmadığından üreticinin maliyetini karşılayamamasına yol açabildiği gibi ayrıca üretilen ürünlerin çoğunlukla il içerisinde tüketildiğini göstermektedir.

\section{Öneriler}

İlgili yerel yönetimlerin sahada arıcılık için potansiyel alanları belirleyerek, bu alanlarda üreticilerin arıcılık faaliyetlerini yürütmelerini teşvik etmeleri ve yönlendirmeleri faaliyetin belirli plan dâhilinde yürütülmesi adına önemlidir.

Sahada gerekli çalışmalar yürütülüp, bu faaliyeti yürütmek isteyen bireylere gerekli teşvikler sağlanarak veya verilen teşvik miktarları arttırılarak işletmelerin büyümesinin sağlanması hem ilin bu alanda sahip olduğu potansiyelinin değerlendirilmesine hem de ilin ve dolaysıyla ülkenin ekonomisine katk1 sağlayacağı düşünülmektedir.

Üreticilere yapılan eğitimlerde iklim ve hava koşullarına ayrı bir önem verilmeli, üreticilerin hava koşulları ile ilgili tahminlerden nasıl yararlanabilecekleri ve ne gibi tedbirler alınması gerektiği konusunda bilgilendirmelerin yapılması büyük önem arz etmektedir.

Arıcıllk ile ilgili kooperatif ve birliklerin bir araya gelerek bu faaliyette daha etkili olmaları ve üreticilere ucuz materyal temin etme konusunda gerekli desteği sağlamaları bu faaliyetin organize bir biçimde yürütülmesi açısından oldukça önemlidir.

Bal üreticilerine saha çalışmaları yaptırılarak yörede yer alan bitki türleri detaylı tanıtılmalı ve bal üretimi için hangi bitkilerin daha uygun olduğu konusunda bilgilendirme yapılmalıdır. 
Bal üreticilerinin bu faaliyeti yürüttükleri sırada karşılaştıkları sorunlardan biri de arı hastalıklarıdır. Üreticilerin neredeyse tamamına yakını ( \% 91) hastalıklarla mücadelede ilaçlama yöntemine başvurmaktadırlar. Üreticilere arı hastalıklarını önleme veya en aza indirgeme konusunda bilgilendirmelerin yapılması hem verim kaybını azaltacak, hem de üründe kaliteyi arttıracaktır.

Gerekirse hububat, findık, şeker pancarı, canlı hayvan kesiminde olduğu gibi bir fiyat belirlenmesi yapılmalı, araştırma sahasında belirli bölgelerde analiz laboratuvarları kurularak üretilen ürünün kalitesi yapılan analizlerle belirlenip fiyatlandırma yapılmalıdır. Ayrıca ürünün il dışındaki pazarlara da ilin coğrafi etiketiyle pazarlanması adına birlik ve kooperatiflerin çalışmalarda bulunması pazarlama olanaklarını arttıracağından özellikle kırsal kesime yeni iş olanakları da açılmış olacaktır.

\section{Araștırmanın Sinırlılıkları ve Gelecek Araștırmalar}

Yapılan araştırma,

- Araştırma, Sivas İli’nin Yıldızeli, İmranlı, Koyulhisar, Gürün ve Divriği ilçeleri ile sınırlıdır.

- Çalışma grubu arazi çalışması sırasında random yoluyla ulaşılan toplam164 bal üreticisi ile sinırlıdır.

$\mathrm{Bu}$ sinırlılıklar göz önünde bulundurularak gelecek araştırmalarda farklı il ve ilçelerde çalışılması, farklı analiz türleri ile uygulamalar yapılması ve daha farklı veri toplama araçları kullanılarak gözlem ve çalışma yapılması önerilebilir.

\section{Yazar Katkıları}

$\mathrm{Bu}$ çalışma arazi gezileri, gözlemleri ve bal üreticilerine uygulanan anketler sonucunda yapılmıştır. Araştırma sahasında verilerin toplanmasında ve değerlendirmesinde üç yazarında katkısı bulunurken, çalışma alanının fiziki coğrafya faktörlerinin araştırılması ve değerlendirilmesi F.K ve A.E'ye sahadaki verilerin toplanıp analiz edilmesi ve yazılması H.K, A.E, F.K'ya aittir. Tüm yazarlar makalenin yayınlanmış halini okuyup kabul etmişlerdir.

\section{Yayın Etiği}

Araştırma ve Yayın Etiği'ne uyuldu

\section{Finansman}

$\mathrm{Bu}$ makale Sivas Cumhuriyet Üniversitesi Bilimsel Araştırma Projeleri Birimi (CÜBAP) tarafindan desteklenen 088 numaralı "Sivas İlinde Bal Üreticilerinin Sorunları ve Çözüm Önerileri” adlı projeden üretilmiştir. 


\section{Teșekkür}

$\mathrm{Bu}$ çalışmanın giderleri için finansman desteğinden dolayı Sivas Cumhuriyet Üniversitesi Bilimsel Araştırmalar Proje Koordinatörlügüu Birimi’ne (CUBAP) teşekkür ederiz.

ORCID

Hakan Koç 누 http://orcid.org/0000-0001-6840-7702

Abdulkadir Ergün (1) http://orcid.org/0000-0003-1753-0131

Fatih Kartal 1 http://orcid.org/0000-0001-9266-5007

\section{Kaynakça}

Amerikan

Yavru

Çürüklüğü

(2015).

https://ankara.tarimorman.gov.tr/Belgeler/liftet/amerikanyavruc $\% \mathrm{C} 3 \% \mathrm{BCr} \% \mathrm{C} 3 \%$ BCgl\%C3\%BCg\%C3\%BC.pdf (Erişim Tarihi: 06.10.2020).

Arıcılık ve Bal Raporu. (2014). Ünye Ticaret Borsası Yayınları.

Atalay, İ. (1987). Türkiye Jeomorfolojisine Giriş. (Genişletilmiş 2. Baskı). Ege Üniv. Edebiyat Fak. Yayınları.

Atalay, İ. (1994). Türkiye Vejetasyon Coğrafyası. Ege Üniversitesi Basımevi.

Cengiz, M., Emsen, B., \& Genç, F. (2010). Bal Arısı (Apis mellifera L.) Kolonilerinde Varroa (Varroa destructor Anderson\&Trueman) Paraziti İle Mücadelede Organik Asitlerin Kullanımı. Türkiye IV. Organik Tarım Sempozyumu, 28 Haziran-1 Temmuz. 50-53. Erzurum.

Üceş, E., Erişir, Z. (2016). Erzincan İli Arıcılı̆̆ının Sosyo-Ekonomik Yapısı. Fırat Üniversitesi Săg. Bilimleri Veteriner Dergisi, 30(1), 33-38.

Ergün, A., Buldur, A. D. (2016). Sivas İlinde Yükselti Basamaklarına Göre 1990-2015 Yılları Arasında Nüfus Ve Yerleşmelerin Dağılışı Ve Değişimi. Zeitschrift für die Welt der Türken (ZfWT), 8(3), 303-327.

Erinç, S. (1996). Klimatoloji ve Metodları. Alfa Basım Yayım Dağıtım.

Karakaya, İ. (2009). Bilimsel Araştırma Yöntemleri. A. Tanrı̈̈̆gen (Editör). Bilimsel Araştırma Yöntemleri kitabı içinde(55-84).

Kaya, F. (2008). Ağrı İlinde Arıcılık Yapısı Ve Değerlendirme Durumu. Atatürk Üniversitesi Sosyal Bilimler Enstitüsü Dergisi, 12(2).

Kekeçoğlu, M., Gürcan, E. K., Soysal, M. İ. (2007). Türkiye Arı Yetiştiriciliğinin Bal Üretimi Bakımından Durumu. Tekirdağ Ziraat Fakültesi Dergisi, 4(2), 227-236.

Nosema Hastalığı (2015). https://ankara.tarimorman.gov.tr/Belgeler/liftet/nosemahastaligikronikarifelcihastali giseptisemihastaligi.pdf (Erişim Tarihi: 15.06.2020).

Orta Anadolu Kalkınma Ajansı (2011). Sivas Tarım Hayvancılık ve Gıda Sektörle Çalışma Grubu Raporu.

Sancak, K., Zan Sancak, A., \& Aygören, E. (2013). Dünya ve Türkiye'de Arıcılık. Arcılık Araştırma Dergisi, 10, 7-13.

Saya, Ö., Güney, E. (2014). Türkiye Bitki Coğrafyas. Ankara: Nobel Yayınları.

Sivas Meteoroloji İl Müdürlüğü (2018). Meteoroloji Bültenleri.

Sivas Valiliği (2011). Sivas İli 2011 Çevre Durum Raporu. Sivas.

Toper Kaygın, A., \& Yıldı, Y. (2006). Bartın Yöresi Bal Arısı (Apis mellifera L.) (Hymenoptera, Apidae) Zararlıları. ZKÜ Bartın Orman Fakültesi Dergisi, 8(10), 64-73. 
Tunçel, H. (1992). Türkiye'de (1966-1986 Yılları Arasında) Arıcılığa Genel Bir Bakış. Türkiye Coğrafyası Araştırma ve Uygulama Merkezi Dergisi, Sayı:1, 98-126.

Yaygın Çiftçi Eğitim Projesi (YAYÇEP). (2001). Arıcılık. Erişim Adresi: http://www.tarimkutuphanesi.com/aricilik_(yaycep)_00471.html.

Yıldırım, A. \& Şimşek, H. (2005). Sosyal Bilimlerde Nitel Araştırma Yöntemleri. Seçkin Yayınları.

https://arastirma.tarimorman.gov.tr/aricilik/Belgeler/istatistik/2018\%20YILI\%20D\%C3\%9

CNYA\%20AR CILIK\%20VER\%C4\%B0LER\%C4\%B0\%2002.03.2020.pdf (Erişim Tarihi: 10.09.2020).

http://www.fao.org/faostat/en/\#data/QL (Erişim Tarihi: 05.10.2020).

http://www.fao.org/faostat/en/\#data/QA (Erişim Tarihi: 05.10.2020). 


\section{Extended Abstract}

\section{Introduction}

Turkey is one of the countries with substantially favorable conditions for beekeeping activities because there is a close relationship between beekeeping activities and climatic conditions, flora, topography and hydrographic conditions. The fact that land formations in Turkey exhibit sudden changes over short distances has led to the differentiation of the climate and vegetation which the lead to differences in plants' flowering periods and flowering durations, making beekeeping a sustainable activity country-wide almost throughout the year. In addition, lack of agricultural fields in the rugged and mountainous areas has caused a shift to animal breeding and beekeeping activities in rural areas where a large section of the population lived until recently. This study was conducted in Sivas, the fourth province of Turkey in regards to honey production after Ordu, Muğla and Adana provinces according to the 2019 data of the Turkish Statistical Institute. Identifying the problems experienced during beekeeping activities and presenting solutions to these problems via interviews conducted with a total of 164 honey producers in Yıldızeli, İmranlı, Koyulhisar, Gürün and Divriği districts of Sivas the districts of Sivas with the highest amount of honey production- is believed to be a significant contribution to both the region and the relevant literature.

\section{Method}

This study utilized the field trips and interview method from among qualitative research methods. The interviews were conducted with the help of the semistructured interview form which was prepared by the researchers with questions that included the parameters mentioned in the purpose of the study. The answers given by honey producers to the questions in semi-structured scale and the opinions and information obtained as a result of field observations were evaluated by descriptive analysis method. The study group of the research consists of 164 honey producers reached randomly during the field study in Y1ldizeli, İmranl, Koyulhisar, Gürün and Divriği districts of Sivas Province. The study group was composed of 164 honey producers randomly reached during the field trips in Yıldızeli, İmranlı, Koyulhisar, Gürün and Divriği districts of Sivas Province. Descriptive analysis method was used to evaluate the responses provided by the participating honey producers to the questions in the semi-structured interview form and the opinions and information obtained as a result of field observations.

\section{Purpose}

Sivas is one of the most important honey producing provinces in Turkey. This study aimed to identify the problems encountered by the honey producers in Sivas Province e and to offer feasible solutions to these problems. In this context, the following parameters were examined in the study: 
-Whether the individuals engaged in beekeeping were migratory beekeepers or domestic beekeepers,

- Bee breeds most preferred by beekeepers

- The start and end periods of beekeeping activities for beekeepers during the year (in months)

- The number of hives owned by each beekeeping enterprise

- Products obtained from beekeeping activities and their quantities (in $\mathrm{kg}$ )

- Whether the amount of products obtained in beekeeping activities changed on an annual basis and if it did, the reasons for this change

- Problems faced by beekeepers in obtaining materials

- Knowledge levels of beekeepers about the climatic characteristics of the area where they carried out beekeeping activities

- Knowledge levels of beekeepers about the plant characteristics of the area where they carried out beekeeping activities

- The problems faced by beekeepers during unfavorable climatic conditions and their methods of dealing with them

- Knowledge levels of beekeepers about other economic activities carried out in the area where they carried out beekeeping activities

- Diseases encountered by beekeepers while carrying out beekeeping activities and the problems related to combating these diseases

- Beekeepers' problems in dealing with intermediaries in regards to marketing the products they produced.

\section{Findings}

Although local beekeepers were found to be predominant in all of the districts where interviews were conducted, it was observed that migratory beekeepers were also high in number especially in İmranl, Koyulhisar and Zara. While the districts most preferred by migratory beekeepers from other cities were found to be İmranl, Koyulhisar and Zara, the migratory beekeepers of Sivas preferred Antalya, Muğla, Mersin and Ordu provinces the most. The migratory beekeepers that went from these provinces to other cities preferred Hatay, Adana, Muş followed by Tokat, Erzincan, Amasya and Osmaniye. It was identified that the highest number of migratory beekeepers who went to other region s were from Divriği (7), Gürün, Koyulhisar and Yıldızeli (6) districts of Sivas.

According to research results, while the Caucasian Honeybee (Apis mellifera caucasia) was the most preferred bee race in the region, Carniolan Honeybee (Apis mellifera carnica), was the most preferred second bee race and mostly used in 
Divriği and Zara districts. It was found that the highest number of beehives in the province was $350-400(11.5 \%)$, between $300-350$ and $100-150(10.4 \%)$ and 150 $200(10.2 \%)$ respectively and the lowest number of beehives was between 200 and $250(5.3 \%)$.

It was determined that there was an increase in the amount of products obtained from beekeeping activities in the periods when the climatic conditions were more favorable while conversely, there was a decrease in the amount of the product in the periods when the climatic conditions were unfavorable. Beekeeping activities in Sivas Province were identified to be more extensive in the period of MarchSeptember followed by the period of January-December. It was found that honey producers in İmranlı started their activities later than the honey producers Divriği, Koyulhisar and Yildizeli districts due to lower monthly average temperatures in İmranl. In Zara, beekeeping activities were found to be extended throughout the year due to the high numbers of migratory beekeepers. It was determined that low productivity level was the most common problem in the research area. In addition, almost all of the honey producers reported having problems in combating diseases and therefore having had to resort to using chemical disinfection.

Annual amount of honey production was determined to be $1000 \mathrm{~kg}$ and above. It was observed that pollen (44.3\%) was the second most important product obtained from beekeeping activities. Although honey producers reported no problems in procuring the materials required for their activities, it was observed that the producers obtained the materials from private organizations rather than institutions or associations operating in this field.

\section{Discussion and Conclusion}

According to the 2019 data of the Turkish Statistical Institute, Sivas is the $4^{\text {th }}$ biggest hony producing province in Turkey. Zara, İmranl, Divriği, Koyulhisar, Hafik, Gürün and Yildızeli districts of Sivas have the highest amount of honey production in the province. Although local beekeepers are predominant throughout the province, there are also a significant ratio of migratory beekeepers and the main problem of migratory beekeepers is finding space. Apart from this, the problems faced by the beekeepers in the city in general are the variation in yield over the years, diseases and high cost of materials. Marketing problems also exist albeit in small ratios.

\section{Implication and Suggestions}

It is important for the relevant local governments to identify potential areas for beekeeping in the region and to encourage and direct the producers to carry out beekeeping activities in these areas in order to carry out the activity within a certain 
plan.

Enabling businesses/enterprises to grow by carrying out necessary studies in the field, providing necessary incentives to individuals who want to carry out this activity or increasing the amount of exciting incentives will not only contribute to the use of the potential of the province in this field but also to the economy of the province and consequently to the country.

Climate and weather conditions should be prioritized in the trainings given to honey producers. It is of great importance to inform the honey producers about how they can benefit from the weather forecast and what measures should be taken under specific conditions.

It is very important that cooperatives and unions in the field of beekeeping come together and become more effective in beekeeping by providing the necessary support in terms of affordable materials so that beekeeping activities can be carried out in an organized manner.

The plant species in the region should be introduced in detail by conducting field studies for honey producers and information should be given about which plants are more suitable for honey production.

One of the problems encountered by honey producers while carrying out their activities is related to bee diseases. Almost all of the producers (91\%) were found to use disinfectants to combat diseases. Informing the producers about preventing or minimizing these diseases will both reduce the loss of yield and increase the quality of the product.

If necessary, a price quote should be established as in cereals, hazelnut, sugar beet and the slaughter of livestock and analysis laboratories should be set up in certain regions in the research field, to determine the quality and the pricing of the product. In addition, since marketing these products to markets outside the province with geotagging by the unions and cooperatives by taking the initiative will increase marketing opportunities, new business opportunities will be created especially for the rural areas.

\section{Research Limitations and Future Research}

This research is limited to the districts of Yıldızeli, İmranlı, Koyulhisar, Gürün and Divriği of Sivas Province and the study group is limited to a total of 164 honey producers reached randomly during the field study.

Considering these limitations, it may be suggested to work in different provinces and districts, to use different types of analyses and to observe and study the phenomenon by using different data collection tools. 


\section{Author Contributions}

This study was conducted with the help of field trips and observations and interview questions directed to honey producers. While all three authors contributed to the collection and evaluation of the data in the research field, F.K and A.E were responsible form the research and evaluation of the physical geography factors of the study area and H.K, A.E, and F.K contributed to collecting, analyzing and writing the data in the field. All authors read and accepted the published version of this article.

\section{Publication Ethics}

Research and Publication Ethics was complied

\section{Funding}

This article is generated from the project nr. 088 "Problems of Honey Producers in Sivas Province and Their Solution Proposals" which is supported by the Scientific Research Projects unit of Sivas Cumhuriyet University (CUBAP).

\section{Acknowledgments}

We are grateful for their financial support of the Scientific Research Projects unit of Sivas Cumhuriyet University (CUBAP). 